\title{
Scientific Investigation of the Paintings from the Agarbiciu (Cluj County) Wooden Church
}

\section{Constantin Măruțoiu ${ }^{1}$, Ioan Bratu ${ }^{2}$, Olivia Florena Nemeș ${ }^{1}$, Dan Nemeș ${ }^{1}$, Călin Neamțu ${ }^{3}$, Zaharie Moldovan ${ }^{2}$, Teofil Tia ${ }^{1}$, Ilina Udrea ${ }^{4}$, Cristian Tigae ${ }^{5}$}

\author{
${ }^{1}$ Faculty of Orthodox Theology, Babes-Bolyai University, Cluj-Napoca, Romania \\ ${ }^{2}$ National Institute for R \& D of Isotopic and Molecular Technologies, Cluj-Napoca, Romania \\ ${ }^{3}$ Technical University of Cluj-Napoca, Cluj-Napoca, Romania \\ ${ }^{4}$ Faculty of Chemistry and Chemical Engineering, Babes-Bolyai University, Cluj-Napoca, Romania \\ ${ }^{5}$ Department of Chemistry, University of Craiova, Craiova, Romania \\ Email: ctigae@yahoo.com
}

How to cite this paper: Măruțoiu, C. Bratu, I., Nemeș, O.F., Nemeș, D., Neamțu, C., Moldovan, Z., Tia, T., Udrea, I. and Tigae, C. (2020) Scientific Investigation of the Paintings from the Agarbiciu (Cluj County) Wooden Church. Journal of Minerals and Materials Characterization and Engineering, 8, 177-196. https://doi.org/10.4236/jmmce.2020.84012

Received: May 3, 2020

Accepted: June 12, 2020

Published: June 15, 2020

Copyright $\odot 2020$ by author(s) and Scientific Research Publishing Inc. This work is licensed under the Creative Commons Attribution International License (CC BY 4.0).

http://creativecommons.org/licenses/by/4.0/

\begin{abstract}
The investigation of the painting materials (pigments, binders and varnish) of Agarbiciu wooden church painted walls was done by employing both nondestructive (XRF and reflection FTIR spectroscopy for pigments) and destructive methods (FTIR spectroscopy and GC-MS spectrometry for pigments and binders). The digital restoration of the interior of the wooden church was done using the physical-chemical composition of the painting layer, a metadata set that describes the timeline, detailed photographic documentation and the $3 \mathrm{D}$ scanned interior of the church.
\end{abstract}

\section{Keywords}

XRF Non-Destructive Analyses, Non-Destructive FTIR Reflectance Analysis, GC-MS Coupling, Digital Conservation

\section{Introduction}

The Agarbiciu village wooden church (Figure 1) is situated in Capusu Mare parish, Cluj county and has The Holy Trinity and Saint Michael and Gabriel Archangels as titular saints, who are the spiritual protectors of Romanians from Ardeal region. The church is situated in the old village cemetery, on the left flank of Agarbiciu valley. The church is built on top of a stone foundation extracted from a local quarry. The walls are built from oak beams horizontally disposed in a Blockbau system, fastened with swallow tail style eyelets. It is a large, well-proportionated edifice with $10 \mathrm{~m} \times 6.5 \mathrm{~m}$ dimensions and positioned on a West-East axis ending with an unhooked altar apse. 
The southern and western flanks of the church are rounded by an open porch. The shingle covered roof is guarded by a bell tower which rises high above the narthex and its crest is flanked by four small turrets. The painting was made by Dimitrie Ispas from Gilau village in two stages: the altar and the nave in 1801 and the narthex and southern facade in 1818. This arises from the two inscriptions above the vestibule separating the nave and narthex. In the first inscription you can find the year of painting, the names of the painter, archpriest, priest (bishop name missing) and the ruling emperor name accompanied with various felicitations and whishing and the fact that the expenses were covered by the villagers (Figure 2).

In the second inscription, you can find the year of the painting, the names of the painter, archbishop, archpriest, priest, curators, the name of the ruling

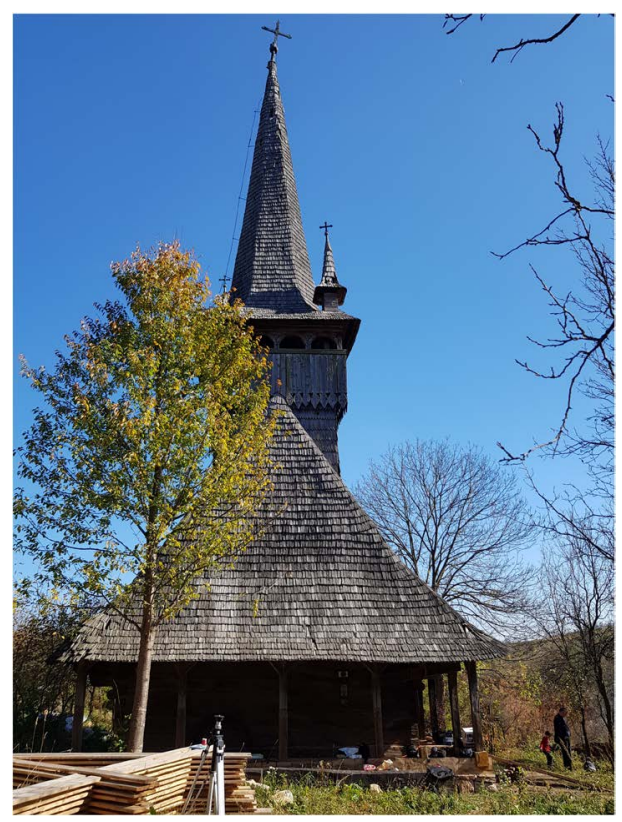

Figure 1. The Agarbiciu village wooden church.

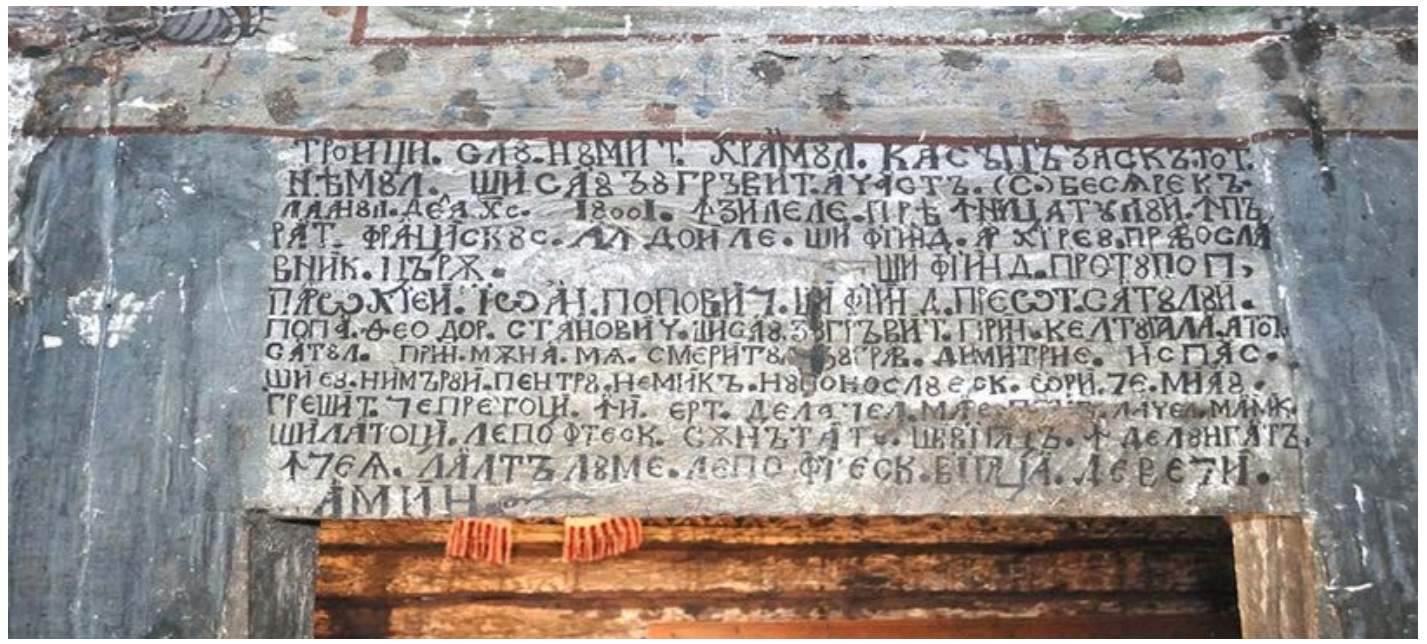

Figure 2. The first inscription above the vestibule separating the nave and narthex. 
emperor and again the fact that the expenses were covered by the villagers (Figure 3) [1]-[6].

Physical-chemical investigations [7]-[13] of the materials used by Dumitru Ispas to paint this church were made to support conservation and restoration activities.

\section{Experimental Methods}

\subsection{Nondestructive Analyses}

Nondestructive analyses were performed using portable devices by approaching them to the paintings (Figure 4-image from altarpiece; Figure 5-image from nave dome; Figure 6-image from narthex roof).

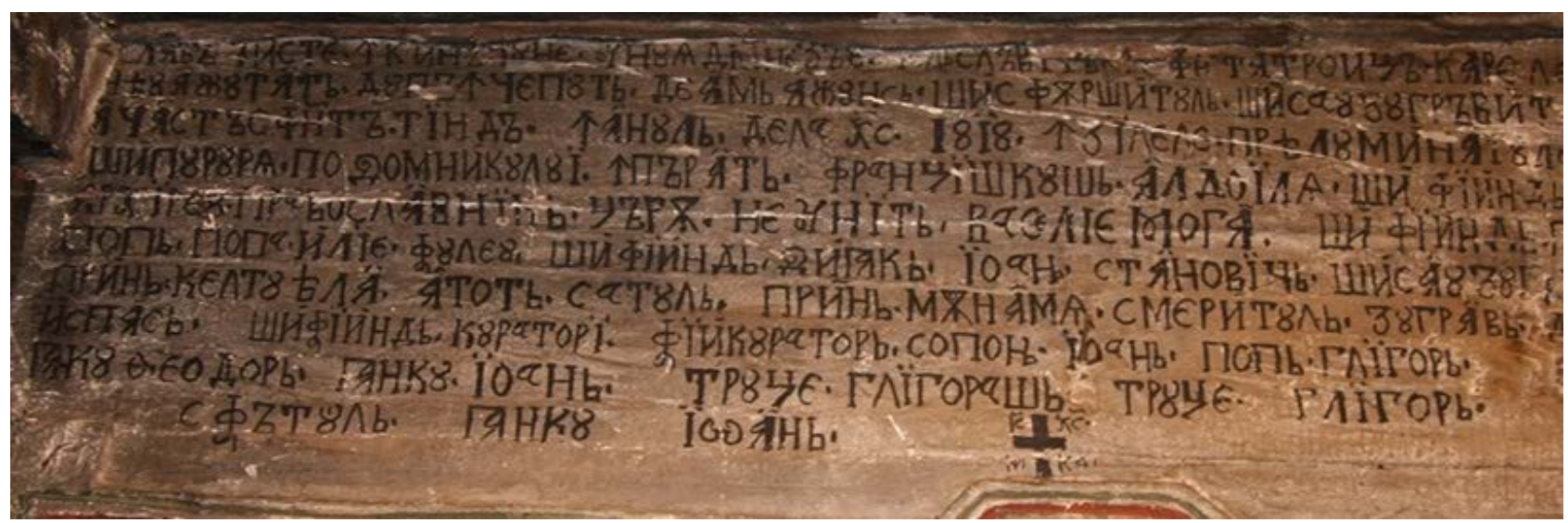

Figure 3. The second inscription above the vestibule separating the nave and narthex.

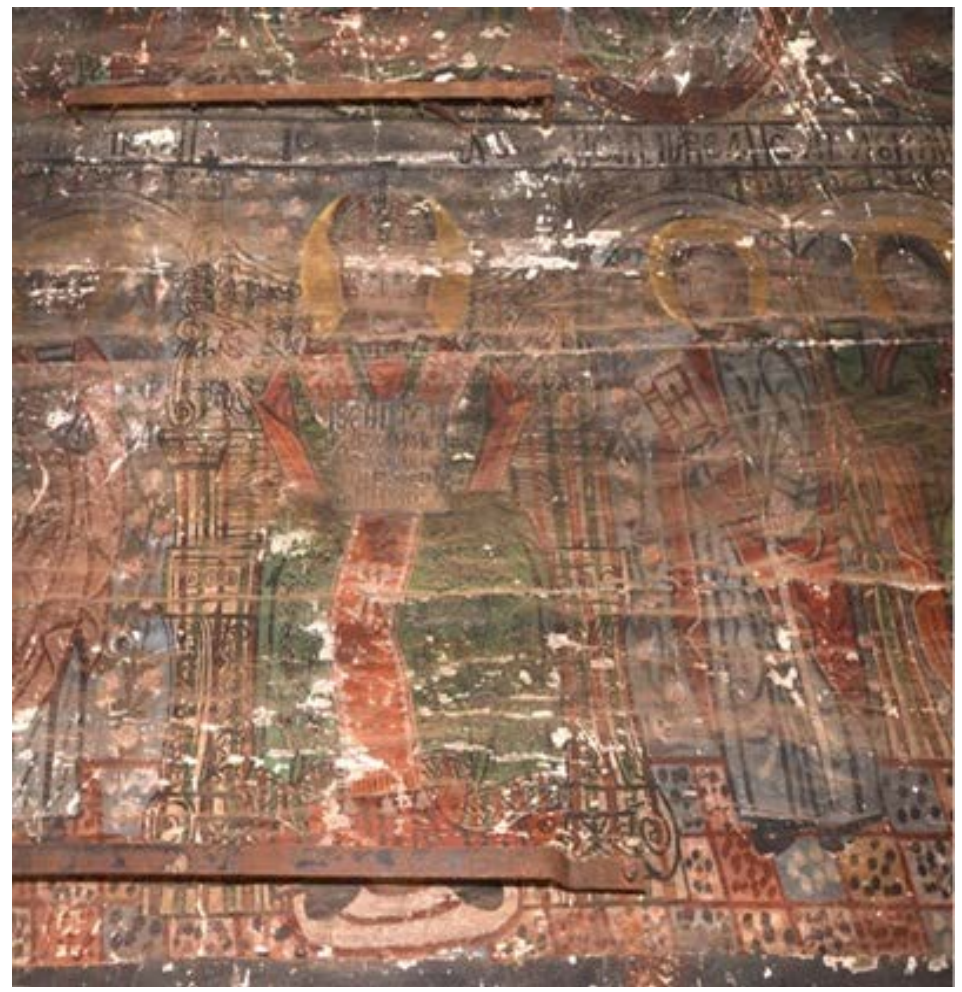

Figure 4. The painting from altarpiece of the wooden church. 


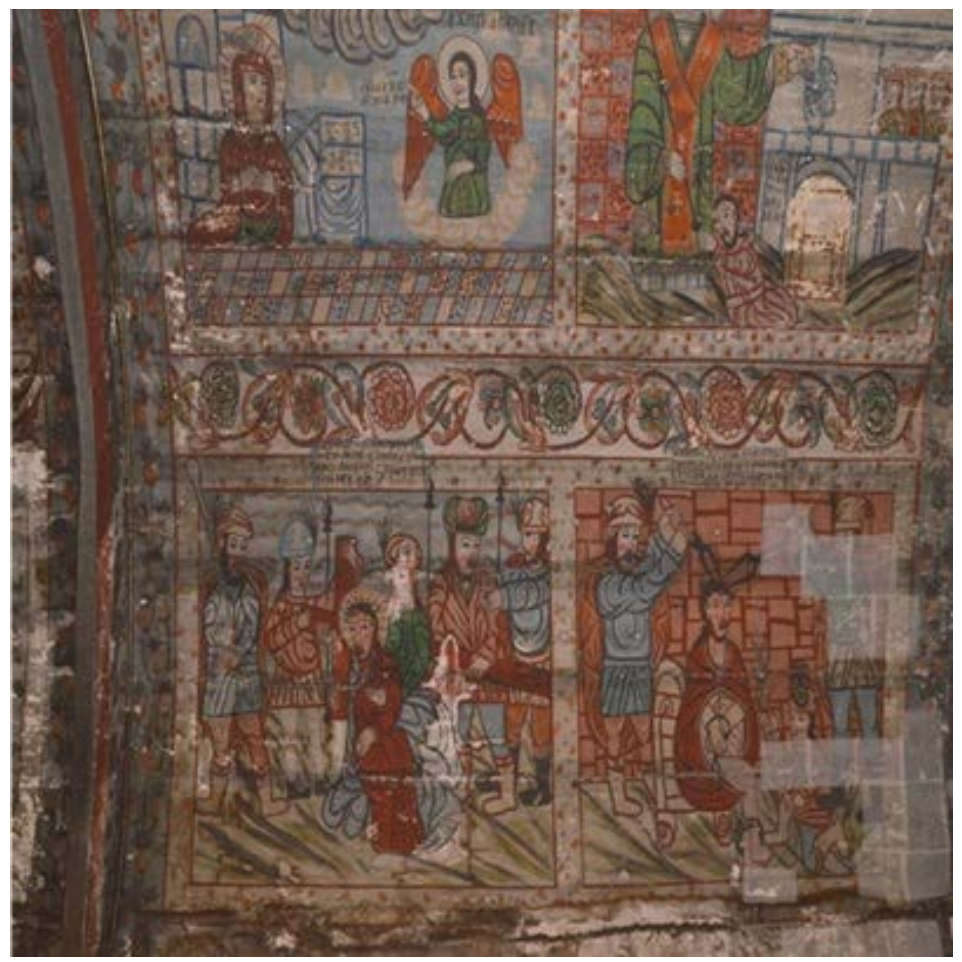

Figure 5. The painting from nave dome of the wooden church.

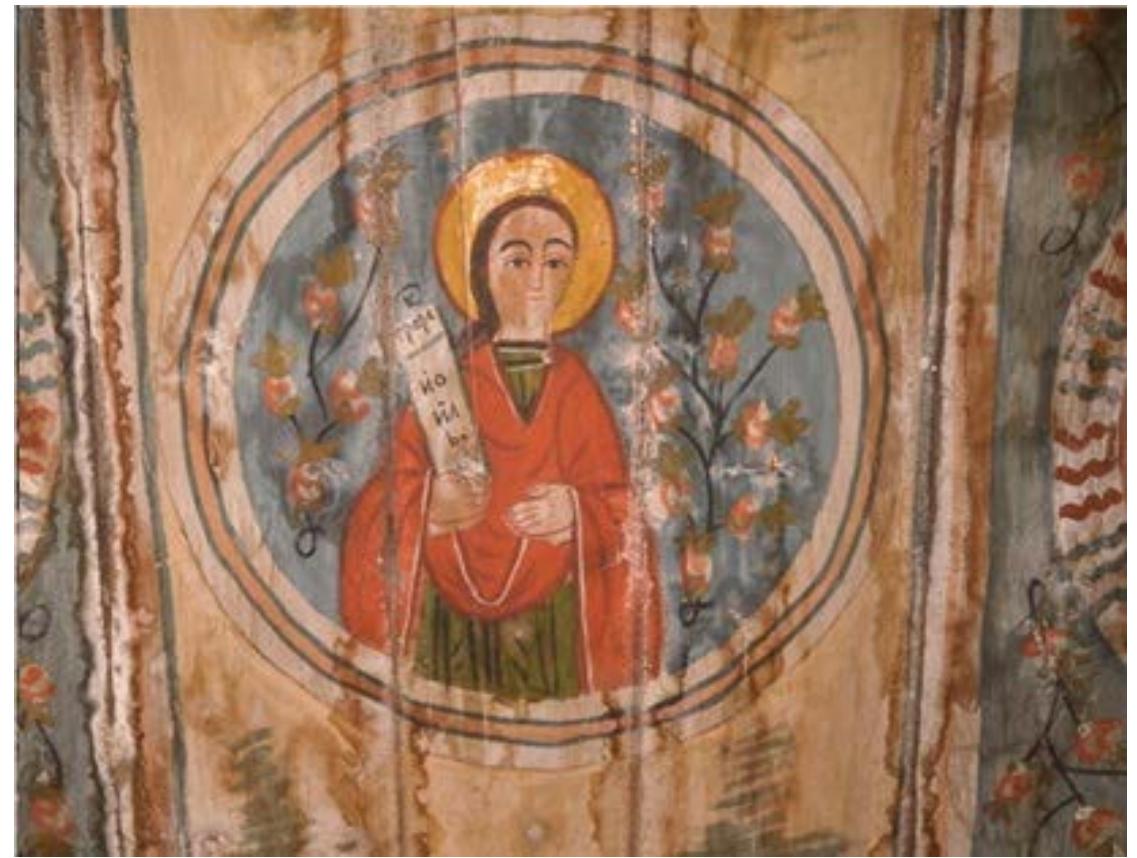

Figure 6. The painting from narthex roof of the wooden church.

FTIR reflectance spectroscopywas performed using a tripod mounted Bruker Alpha II device with a contactless forward looking reflection unit specialized for paintings, spectral domain $400-4000 \mathrm{~cm}^{-1}$, resolution $2 \mathrm{~cm}^{-1}$, OPUS /IR software in Windows 10.

Non-destructive X-ray fluorescence elemental analyses (XRF) was performed 
with a handheld Bruker spectrometer, S1 TITAN series (EDXRF) configured with a Silicon diode PIN detector (SiPIN), Rh target X-ray tube with a maximum voltage of $50 \mathrm{kV}$.

\subsection{Destructive Analyses}

The samples for destructive analyses were collected from areas where the painting layer was exfoliated in order to not damage the painting.

\section{Destructive FTIR Spectroscopy}

FTIR spectra were obtained by employing the well-known $\mathrm{KBr}$ pellet technique. The measurements were done with a Jasco FTIR spectrometer in the 4000 to $400 \mathrm{~cm}^{-1}$ spectral domain with a resolution of $4 \mathrm{~cm}^{-1}$.

Gas Chromatography-Mass Spectrometry (GC-MS)

The sample extracts were analyzed with an analytical system (Thermo Electron Corporation) equipped with a Gas Chromatograph (Trace Ultra) coupled with an ion trap mass spectrometer (Polaris Q).

Mass spectrometer experimental conditions were: electron impact $70 \mathrm{eV}$, ion source temperature $250^{\circ} \mathrm{C}$. Chromatographic separations were achieved on a DB $5 \mathrm{~ms}$ (30 m, $0.25 \mathrm{~mm}$ i.d.) fused-silica capillary column with a $0.25 \mu \mathrm{m}$ film dimethysiloxane (5\% phenyl groups). The injection was in the mode split less with injector set at $250^{\circ} \mathrm{C}$. As eluent gas helium was used at flow rate $2 \mathrm{~mL} / \mathrm{min}$. Oven temperature was programmed from $90^{\circ} \mathrm{C}(1 \mathrm{~min})$ at $120^{\circ} \mathrm{C}(0 \mathrm{~min})$ to $10^{\circ} \mathrm{C} / \mathrm{min}$ and then at $190^{\circ} \mathrm{C}(0 \mathrm{~min})$ to $3.5^{\circ} \mathrm{C} / \mathrm{min}$ and then at $4^{\circ} \mathrm{C} / \mathrm{min}$ to $300^{\circ} \mathrm{C}$ (held 20 $\min )$.

Sampling procedures: The samples were dissolved in ethanol (Promochem, LGC Standards GmbH, Wesel, Germany) and mixed in an ultrasonic bath two stage of $10 \mathrm{~min}$ each maintained at $40^{\circ} \mathrm{C}$. The sample was centrifuged 5 minutes at $3000 \mathrm{rot} / \mathrm{min}$ and then $2 \mu$ of supernatant was injected. In this condition the fatty acids were derivatized to ethyl ester fatty acids.

The investigations were performed for each colour from the following paintings.

\section{Results and Discussions}

\subsection{XRF Non-Destructive Analyses}

XRF results from the investigations are shown in Figures 7-17.

\subsection{Non-Destructive FTIR Reflectance Analysis}

From the reflectance spectrum (Figure 18) - one can identify the presence of Prussian blue $\left(2132.75 \mathrm{~cm}^{-1}\right)$, calcium carbonate $\left(1447 \mathrm{~cm}^{-1}\right)$, collagen $(1288.18$ $\mathrm{cm}^{-1}$ and $\left.712.97 \mathrm{~cm}^{-1}\right)$, egg yolk protein $\left(1541.07 \mathrm{~cm}^{-1}\right)$, gypsum $3403 \mathrm{~cm}^{-1}, 621$ $\mathrm{cm}^{-1}$, spectral domain $4000-400 \mathrm{~cm}^{-1}$.

\subsection{Destructive Analyses}

FTIR spectroscopic absorption spectra of red painting material obtained from 


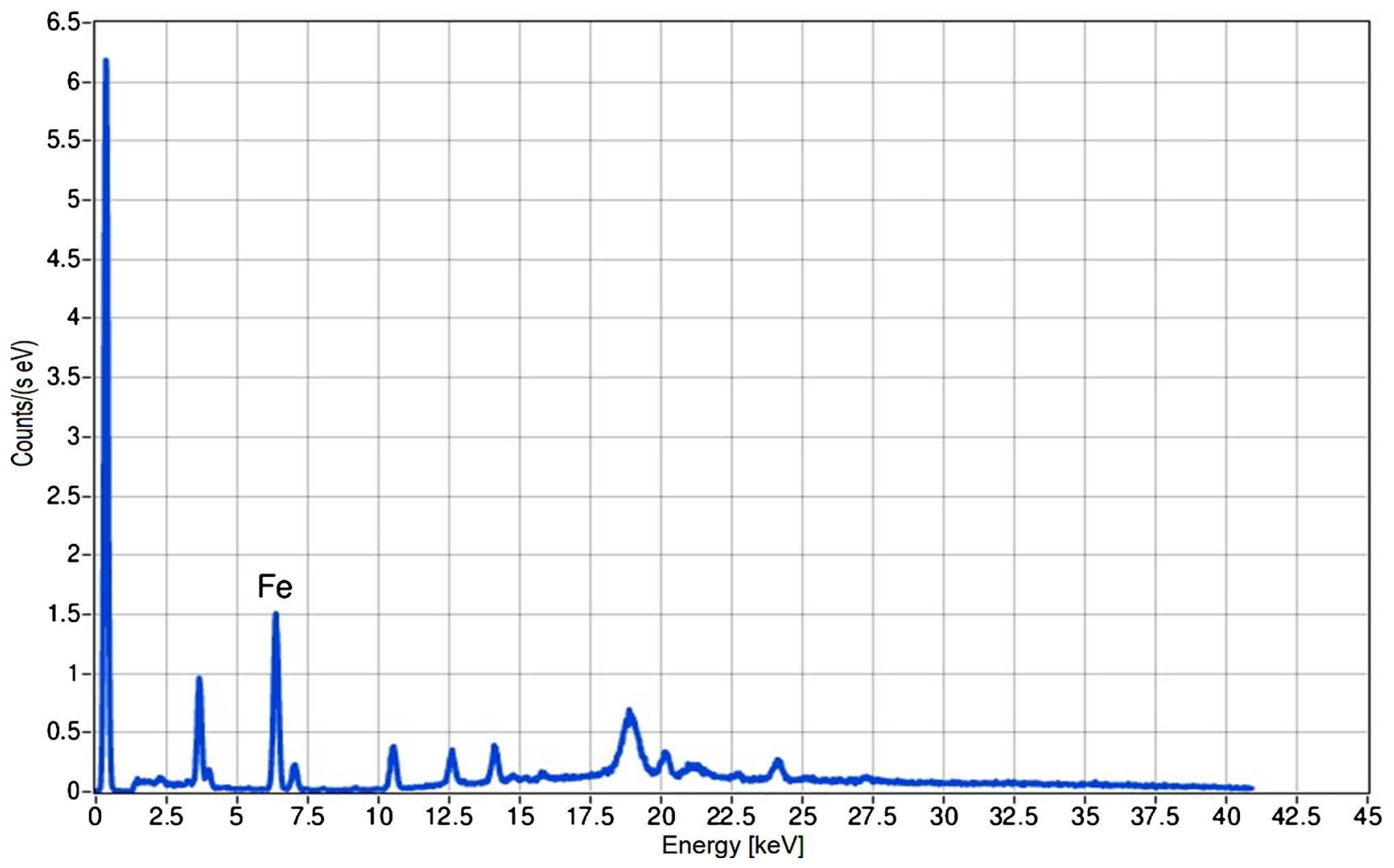

Figure 7. XRF spectrum for red colour from nave. The iron demonstrates de presence of iron oxide.

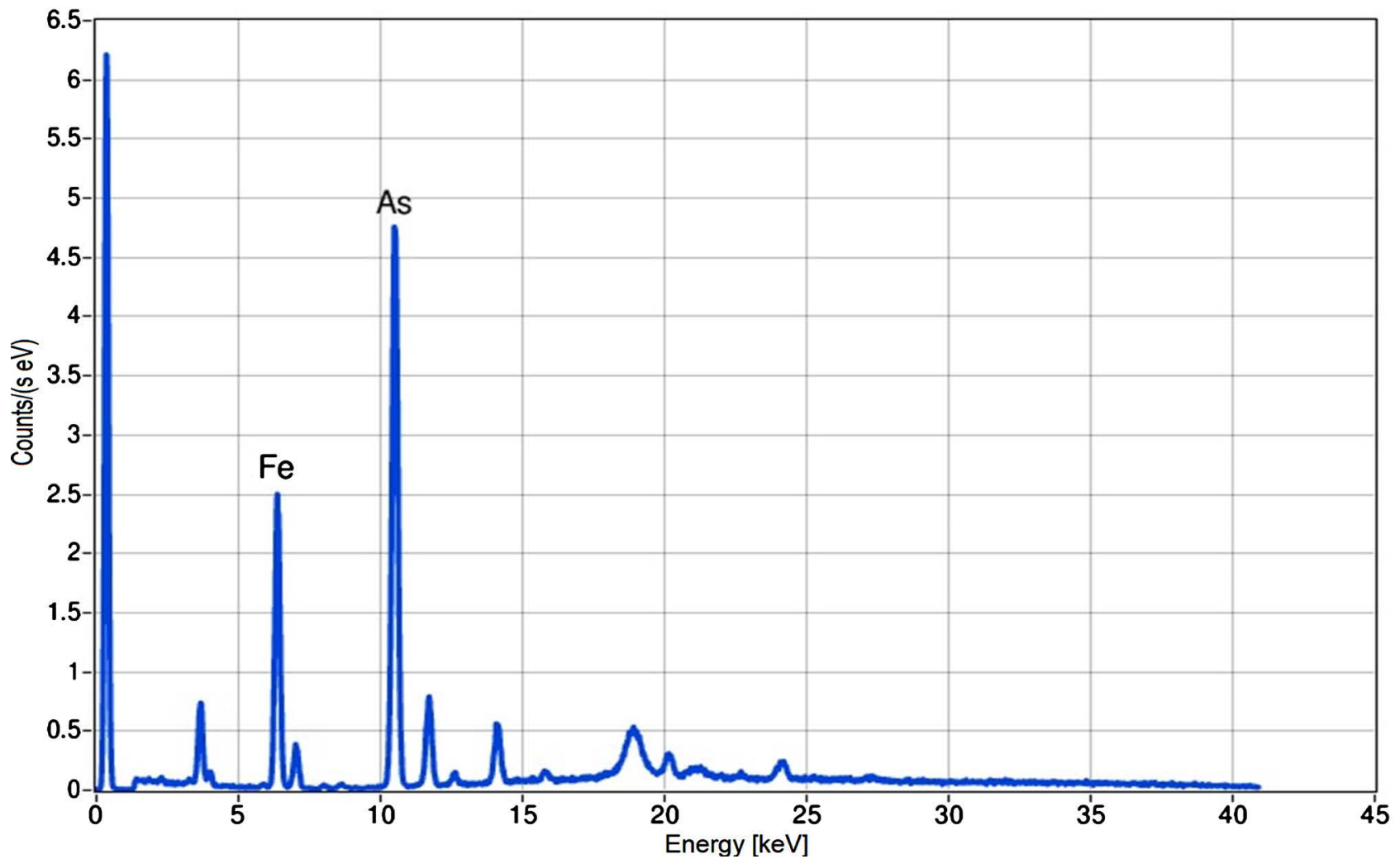

Figure 8. XRF spectrum for red colour from nave (Iron red + Arsenic red mixture). The presence of As red and iron oxides demonstrates the composition of red pigment. 


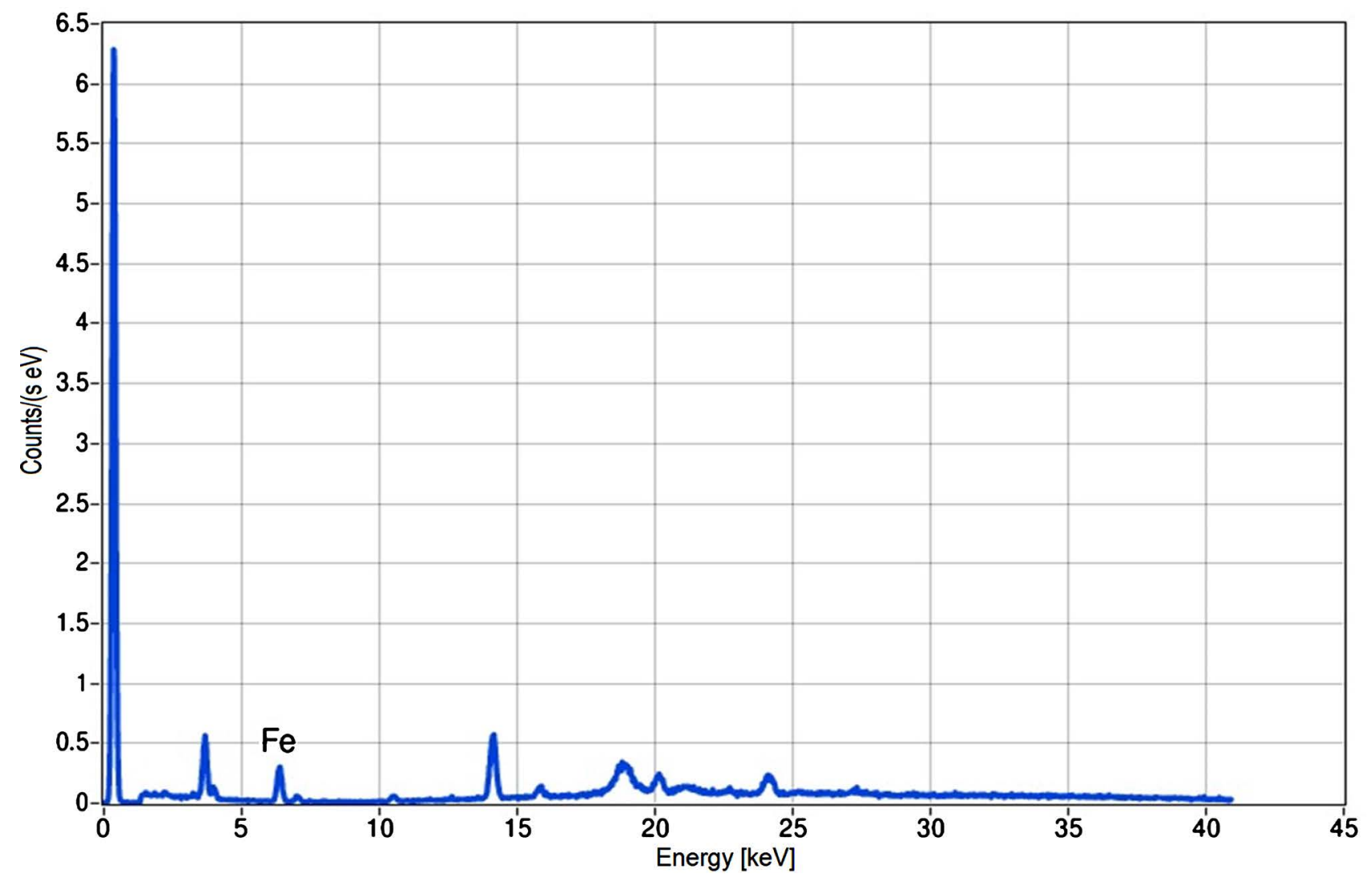

Figure 9. XRF spectrum for black colour from nave. The black pigment contained carbon and iron oxide.

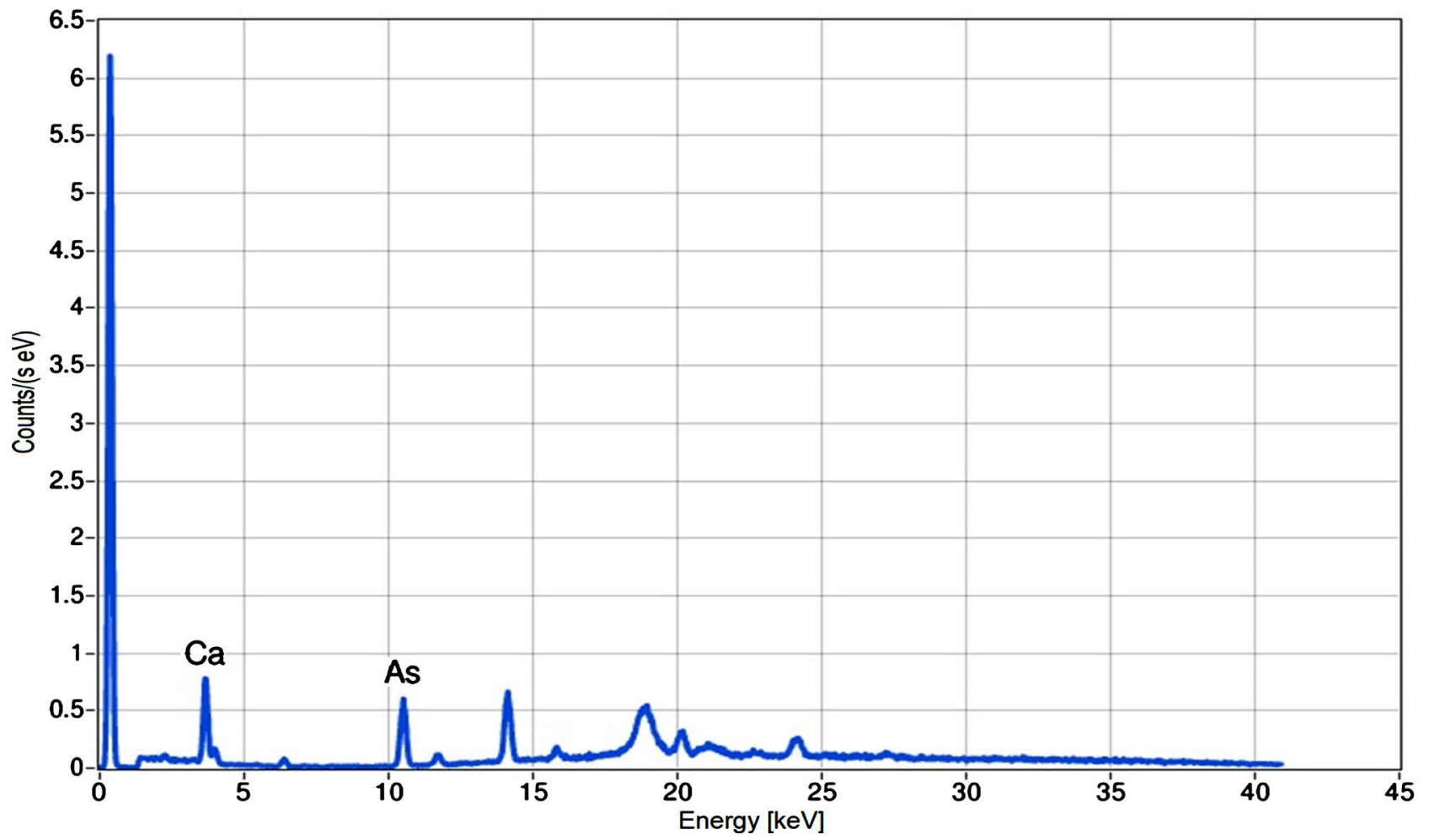

Figure 10. XRF spectrum for yellow colour from aura (nave). The yellow color was done by the presence of orpiment $\left(\mathrm{As}_{2} \mathrm{~S}_{3}\right)$, the presence of Ca was due to the white calcite. 


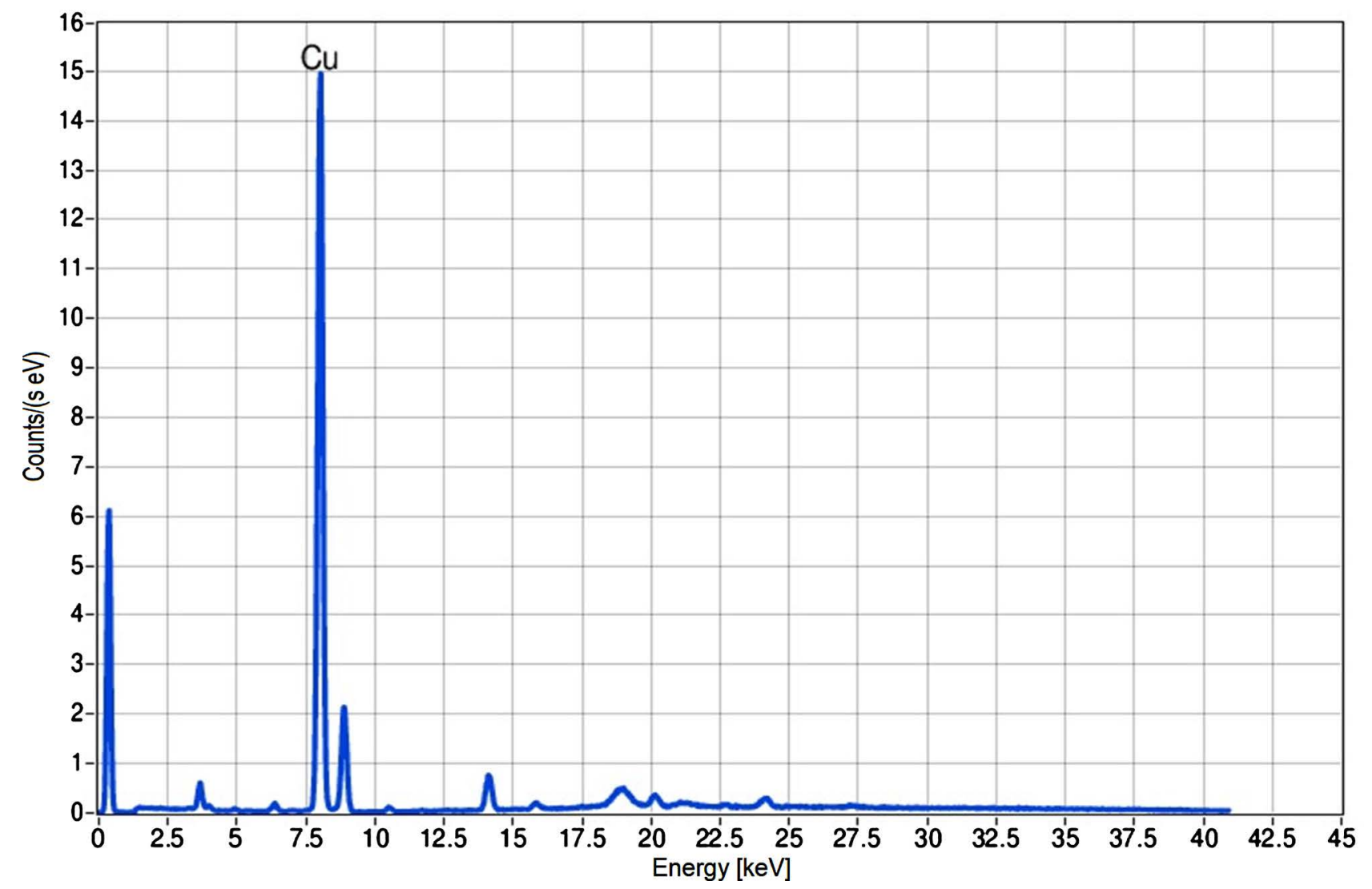

Figure 11. XRF spectrum for green colour from nave. The copper demonstrates the presence of malachite as green pigment.

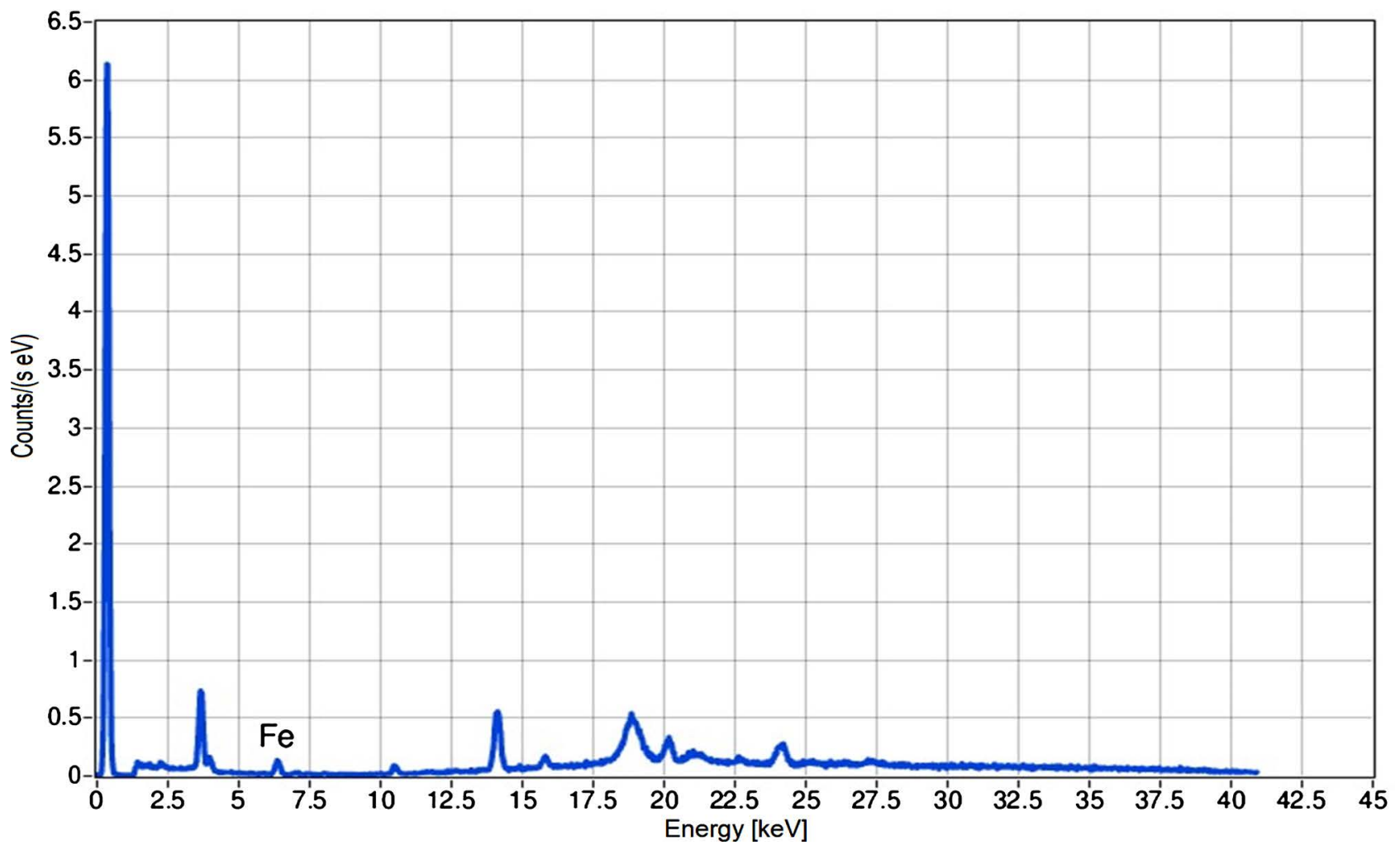

Figure 12. XRF spectrum for blue colour from nave. The iron demonstrates the traces of Prussian blue pigment. 


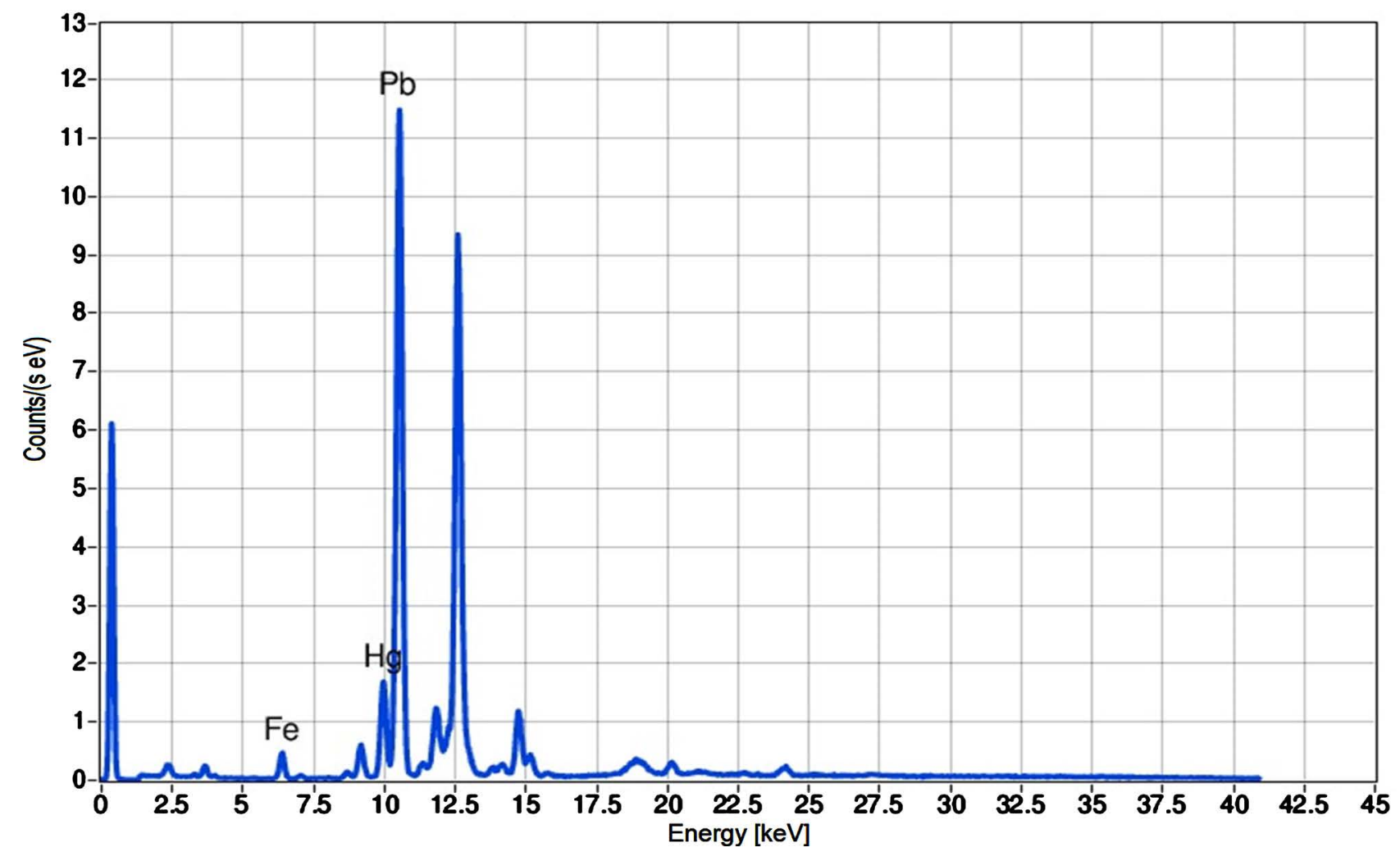

Figure 13. XRF spectrum for red colour from narthex (mixture of $\mathrm{Fe}, \mathrm{Pb}$ and $\mathrm{Hg}$ red). The red pigment contained a mixture of iron and lead oxides and mercury sulphide.

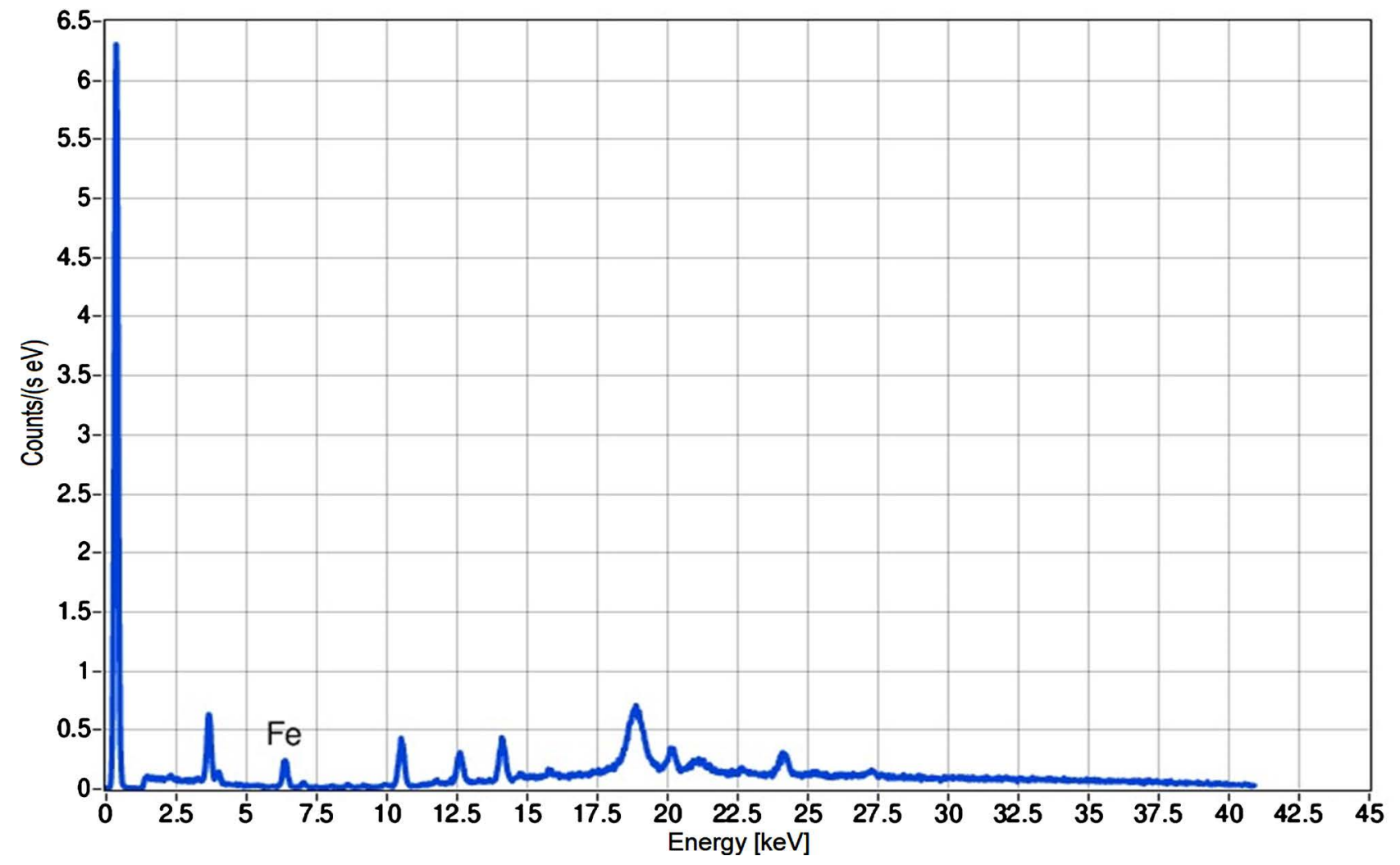

Figure 14. XRF spectrum for black colour from narthex. The black pigment contained carbon and iron oxide. 


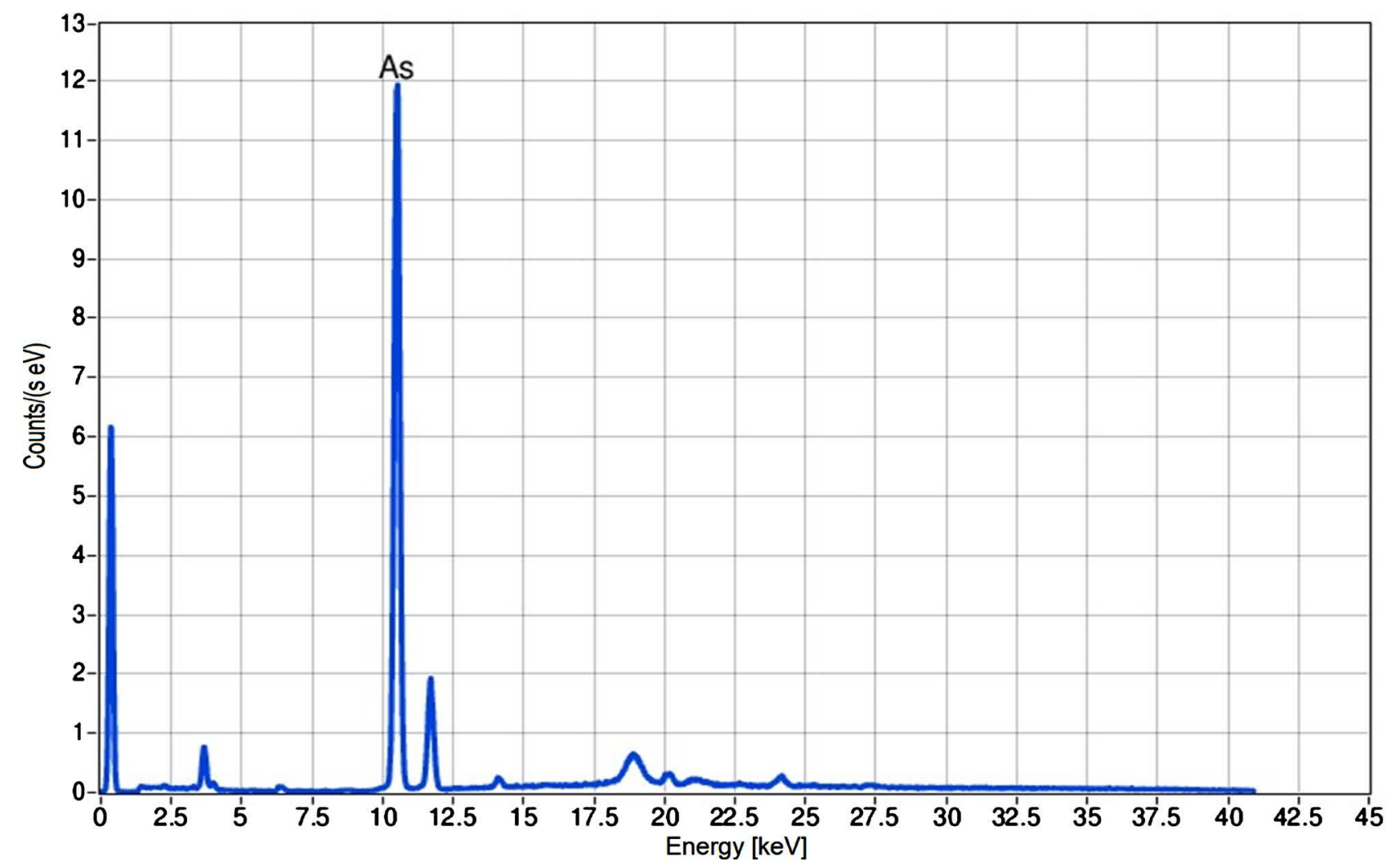

Figure 15. XRF spectrum for yellow colour from aura (narthex). The yellow pigments are based on orpiment $\left(\mathrm{As}_{2} \mathrm{~S}_{3}\right)$.

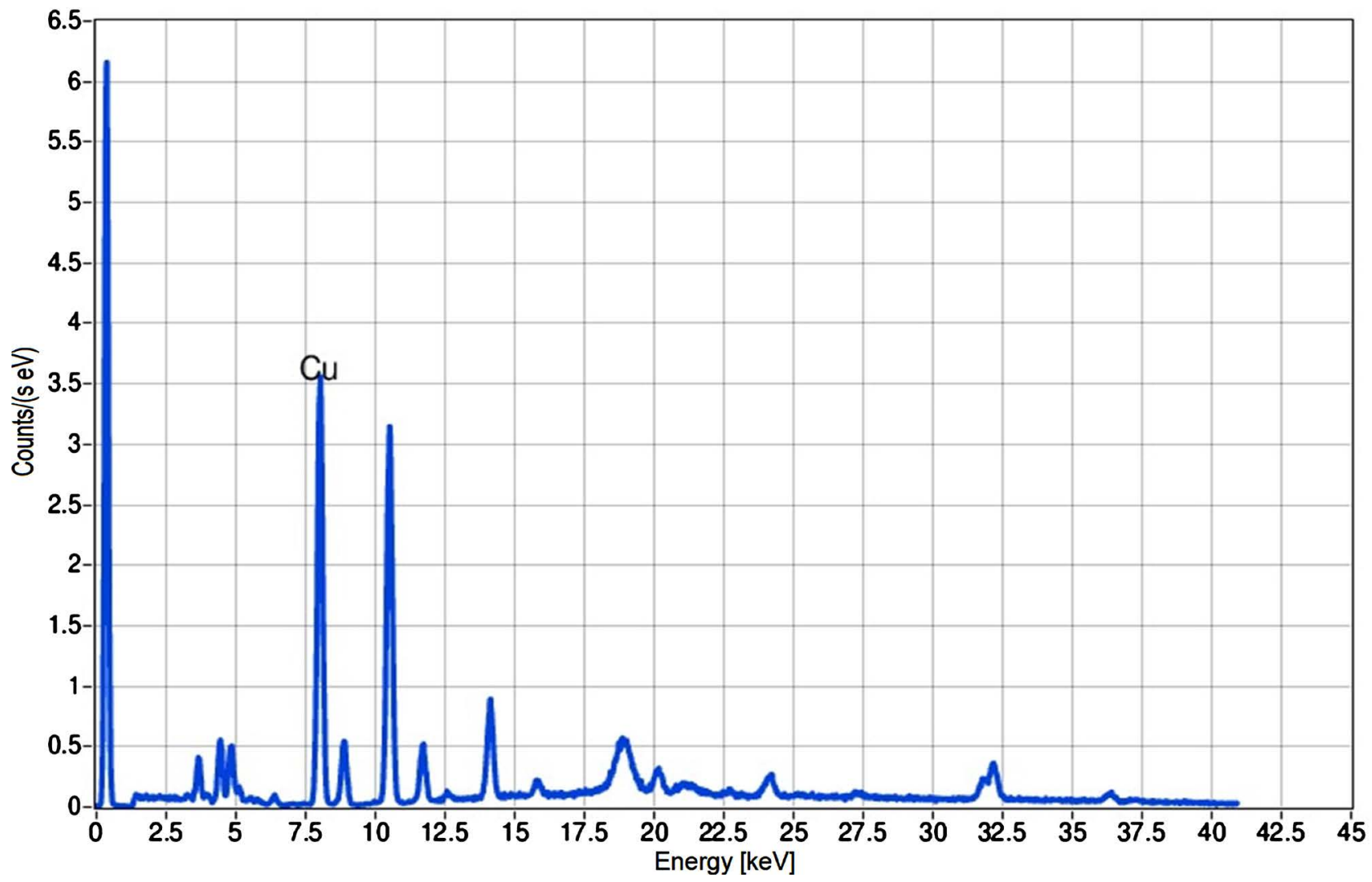

Figure 16. XRF spectrum for green colour from narthex. The presence of malachite is also demonstrated. 


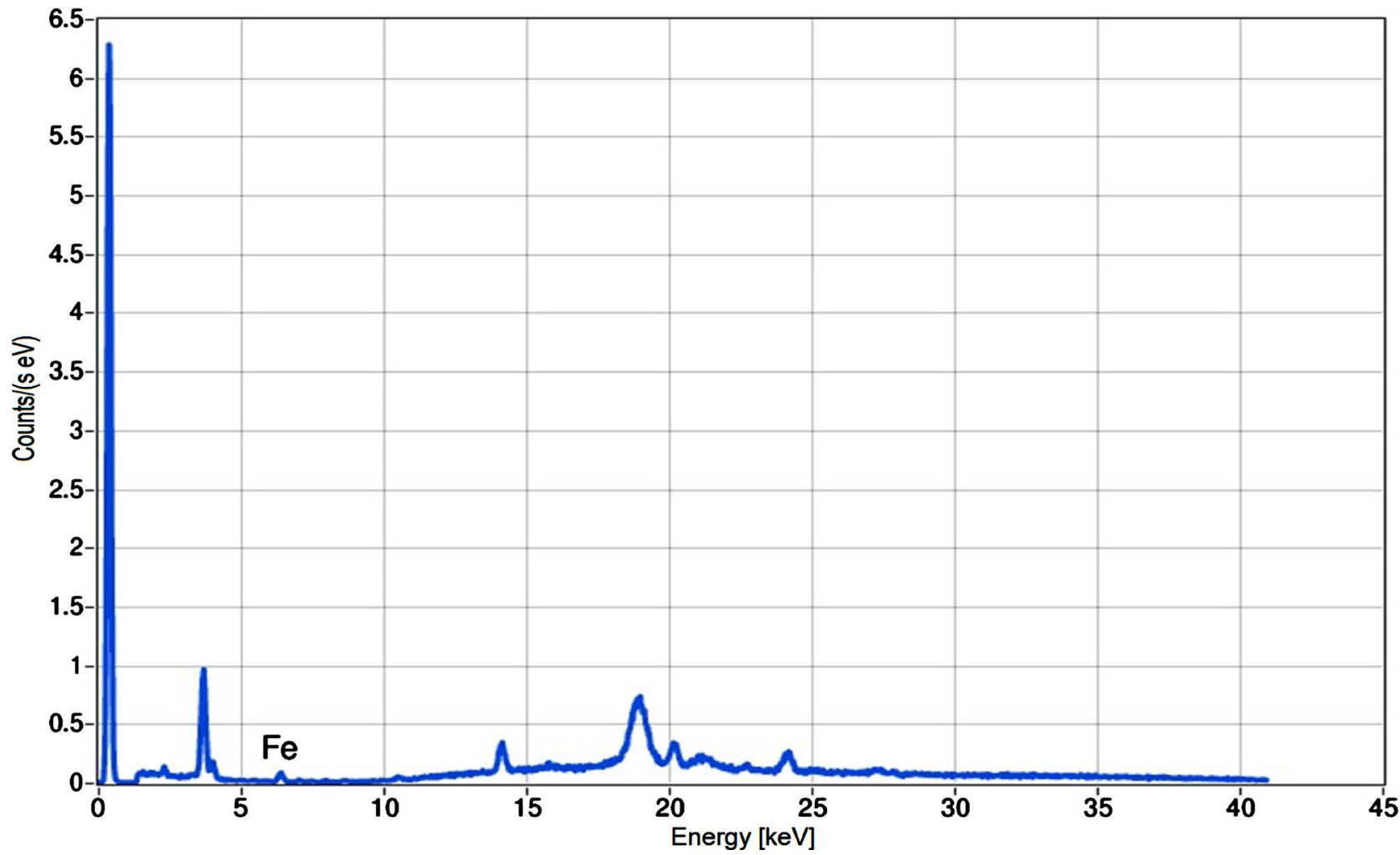

Figure 17. XRF spectrum for blue colour from narthex. The Prussian blue pigment is demonstrated by the iron presence in the XRF diagram.

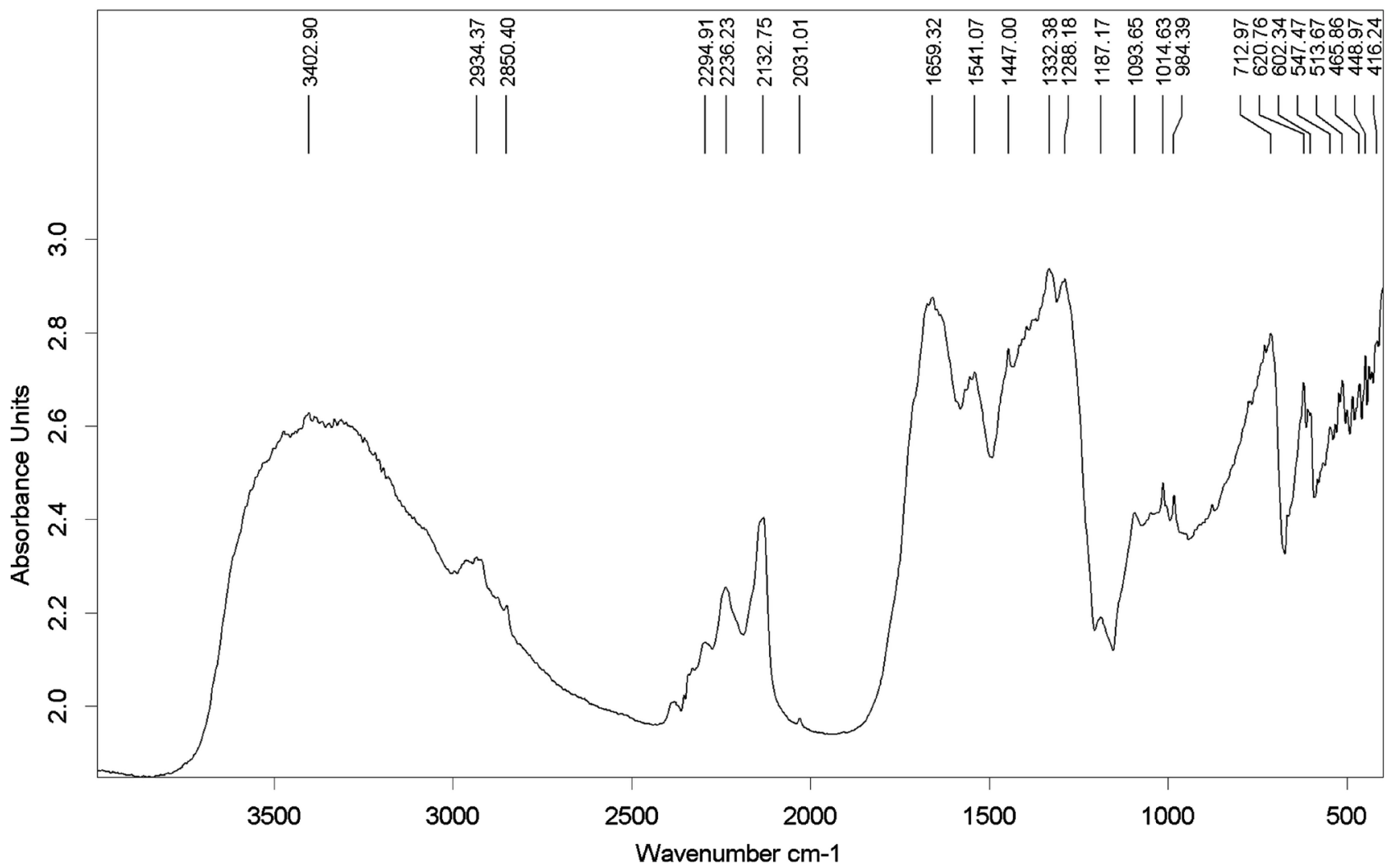

Figure 18. FTIR Spectrum (non-destructive) for blue pigment. 
the southern and northern wooden walls of the church are presented in Figure 19.

From both destructive and non-destructive FTIR analyses the following materials were identified: ground-gypsum, white chalk, Prussian blue; binder-egg yolk, linseed oil (tempera), animal glue.

\section{Identification of linseed oil in the painting layer by GC-MS coupling}

We used a simple GC/MS method for the identification of specific molecular biomarkers of drying oils and lipids used in old art works. Common molecular biomarkers are individual fatty acids. The relative concentration of fatty acids is a very useful indicator for identification of glycerolipids [14] [15] [16]. The procedure was applied for the characterization of two old paint microsamples. The GC/MS chromatogram (TIC) of ethylated palmitic, linoleic, oleic and stearic fatty acids are shown in Figure 20 and their relative concentrations are presented in Table 1.

The quantitative determination of monocarboxylic fatty acids allows us to distinguish between different triglycerides sources (drying oil or egg) on the basis of characteristic parameters [15]. The ability to recognize original materials is due to the use of molecular markers that remain stable under aging.

The unsaturated fatty acids were excluded from classification rules based on previous works [15] that found the ratios of these compounds are dependent on drying and aging conditions. We used the $\mathrm{C} 16: 0 / \mathrm{C} 18: 0$ ratios to discriminate between binders. This parameter is fairly constant for each binder and independent of both the aging treatment and the pigment. This ratio (P/S) can be used to identify each type of drying oil and is not affected by the aging process [14] [15] [16].

From Table 1, it results in that the ratio P/S is 1.02 for Sample 1 and 1.06 for Sample 2. According to the $\mathrm{P} / \mathrm{S}$ value, it was suggested that linseed oil was used as

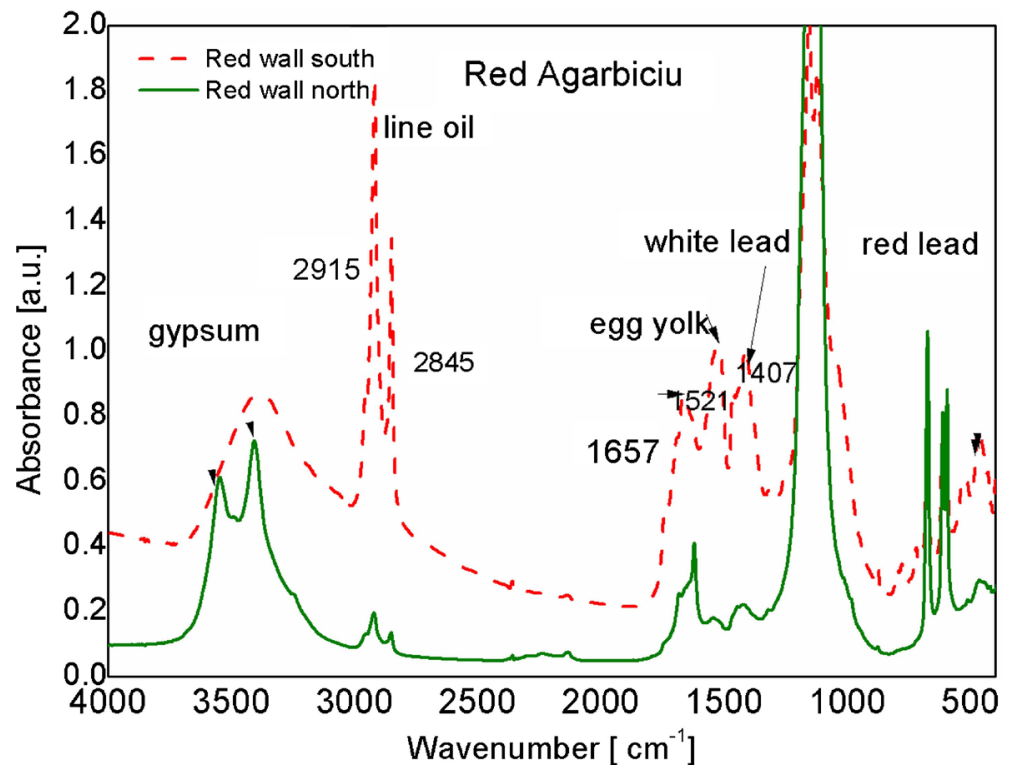

Figure 19. FTIR absorption spectra of red painting material. 


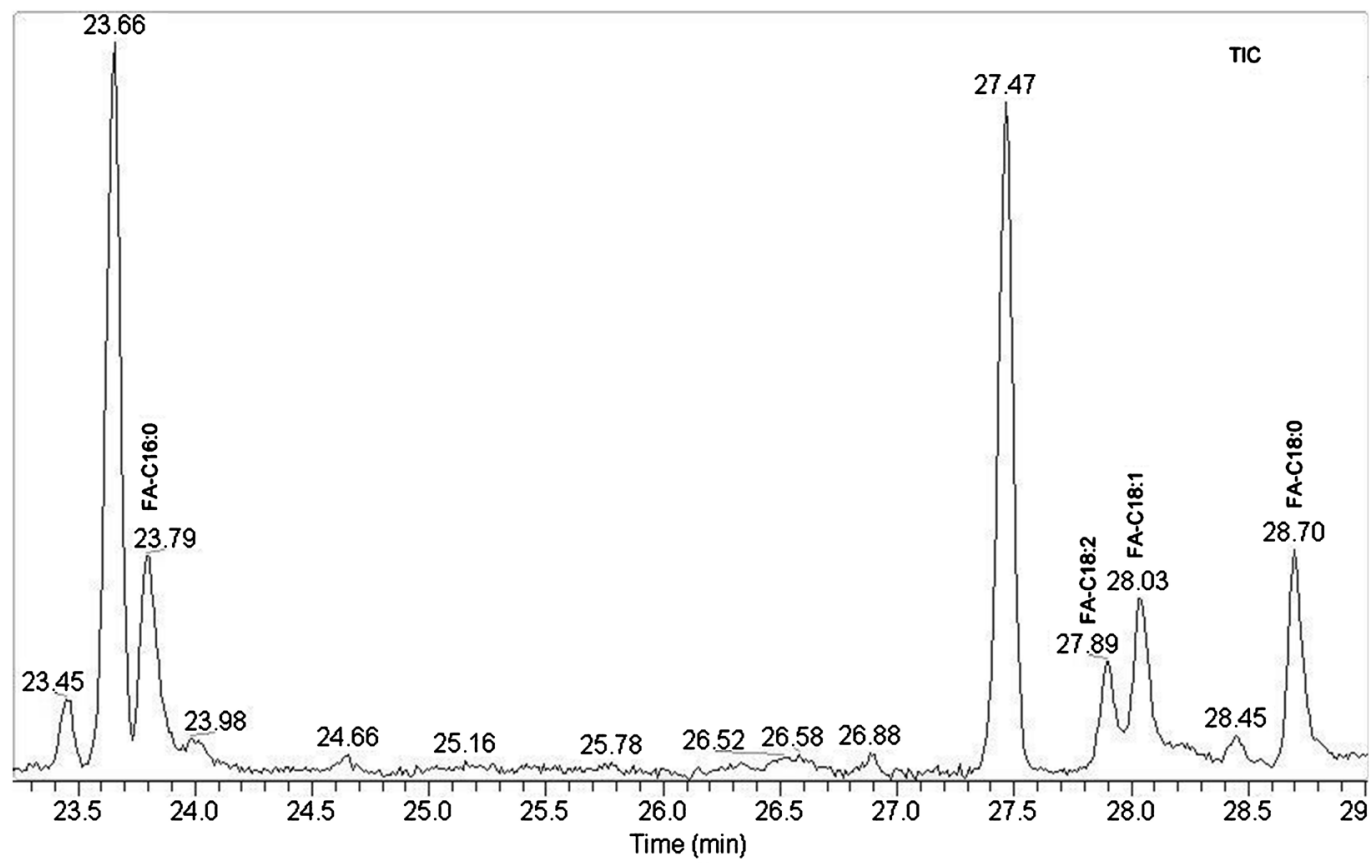

Figure 20. GC/MS Chromatogram (TIC) of: the Palmitic acid ethyl ester (C16:0), the Linoleic acid ethyl ester (C18:2), the Oleic acid ethyl ester (C18:1) and the Stearic acid ethyl ester (C18:0).

Table 1. The relative concentrations of the fatty acids C16 and C18 detected in the studied samples determined from TIC peak area.

\begin{tabular}{ccccc}
\hline No. crt. & Fatty acid & Characteristic ions & $\begin{array}{c}\text { (\%) } \\
\text { Sample 1 }\end{array}$ & $\begin{array}{c}\text { (\%) } \\
\text { Sample 2 }\end{array}$ \\
\hline 1 & Palmitic acid ethyl ester (C16:0) & $73,87,101 \ldots 255,284$ & 29.78 & 41.35 \\
2 & Linoleic acid ethyl ester (C18:2) & $67,81,95,109,262,308$ & 15.68 & 2.68 \\
3 & Oleic acid ethyl ester (C18:1) & $67,81,95,109,264,310$ & 25.35 & 17.09 \\
4 & Stearic acid ethyl ester (C18:0) & $73,87,101 \ldots 283,312$ & 29.19 & 38.86 \\
\hline
\end{tabular}

a binder. The presence of traces of cholesterol leads to conclusion that small quantity of egg can be also present in the binder material. Our results agree with the results reported earlier.

The compounds detection from the "Agarbiciu green and binder" sample, based on selected ions (Figure 21): (a) m/z 101, palmitic and stearic acids; (b) $\mathrm{m} / \mathrm{z}$ 301, cholesterol. The detected compounds are specific to vegetable oils and egg yolk.

\subsection{Digital Conservation}

The digital preservation of the interior of the wooden church will be done using a metadata set that describes the timeline, the physic-chemical composition of the painting layer, detailed photographic documentation and the $3 \mathrm{D}$ scanned interior of the church.

Following the physicochemical analyzes described in the previous chapter, the pigments used for the church interior painting can be obtained in the laboratory (Figure 22) digitized and preserved digitally. 
The pigments can be used in the process of digital repainting to eliminate the effect of time and other factors that degraded the painting layer (Figure 23).

The documentation of the current preservation status of the painting layer has been made digitally using detailed photography within the visible spectrum, IR and UV (Figure 24).

The photographic documentation was done using professional equipment (Canon 5DSLR, $50 \mathrm{Mpx}$ ), the light was measured and recorded every 10 minutes using a spectrometer (Sekonic C7000) (Figure 25), the acquired data will be archived together with the pictures in RAW file format.

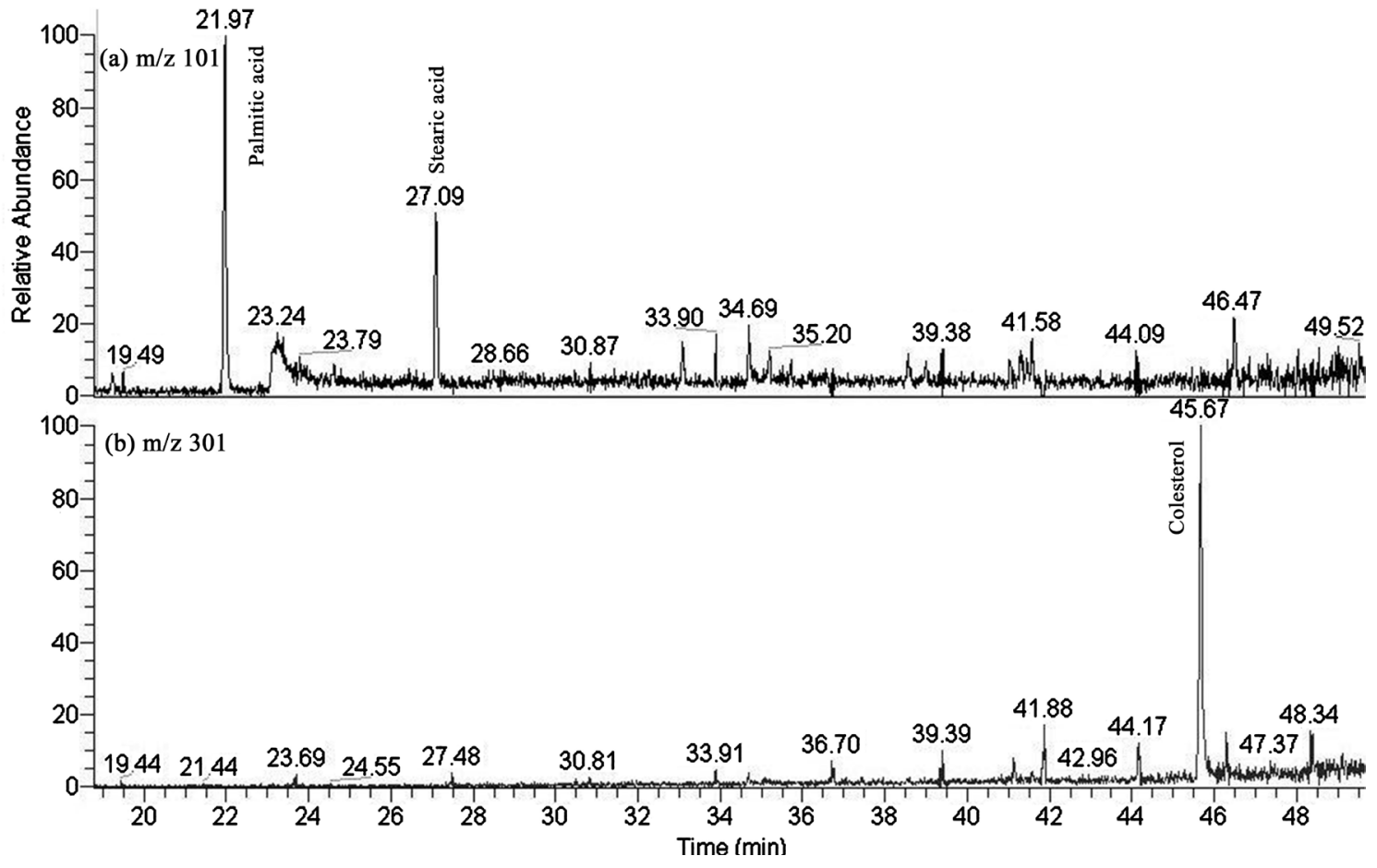

Figure 21. GC/MS chromatogram on selected ions: m/z 101 (palmitic and stearic acid) and m/z 301 (cholesterol).

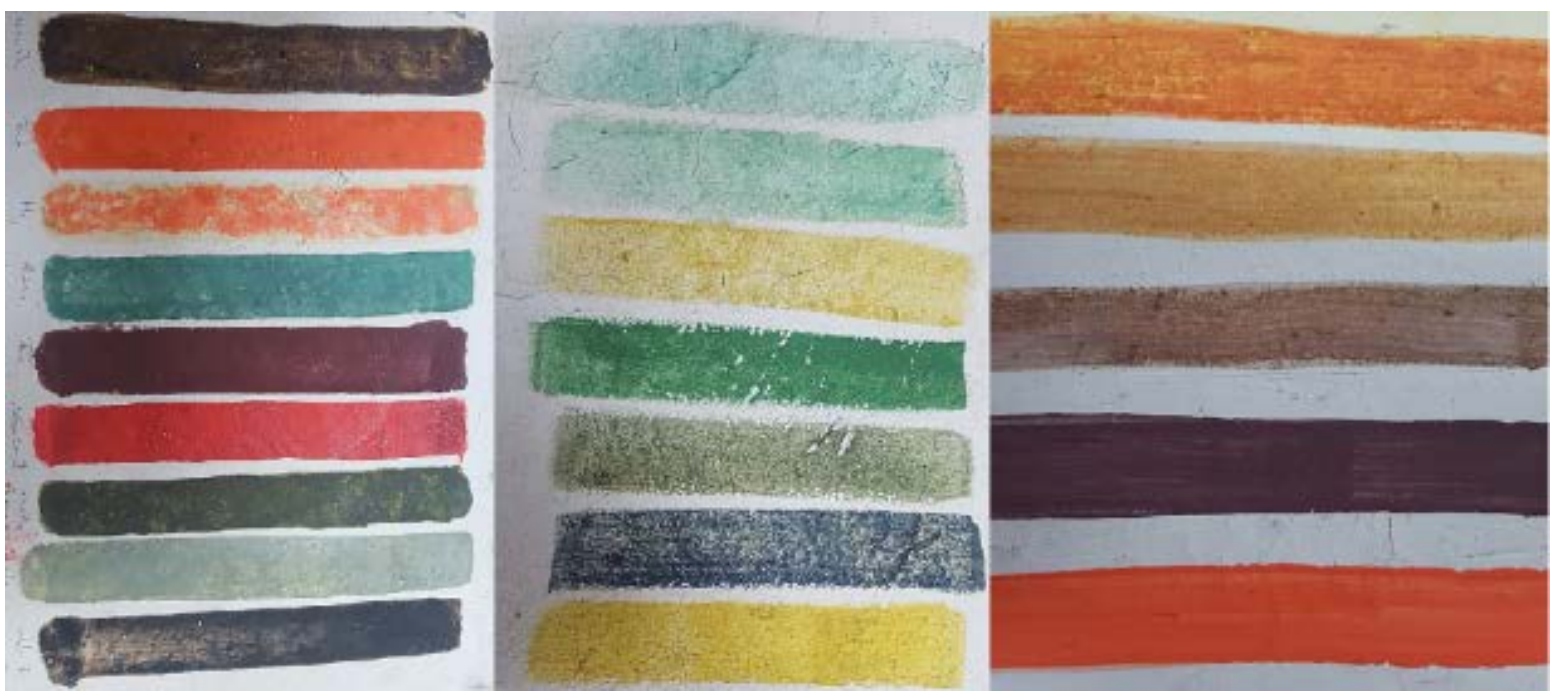

Figure 22. Pigments obtained on the basis of the physico-chemical analyses. 


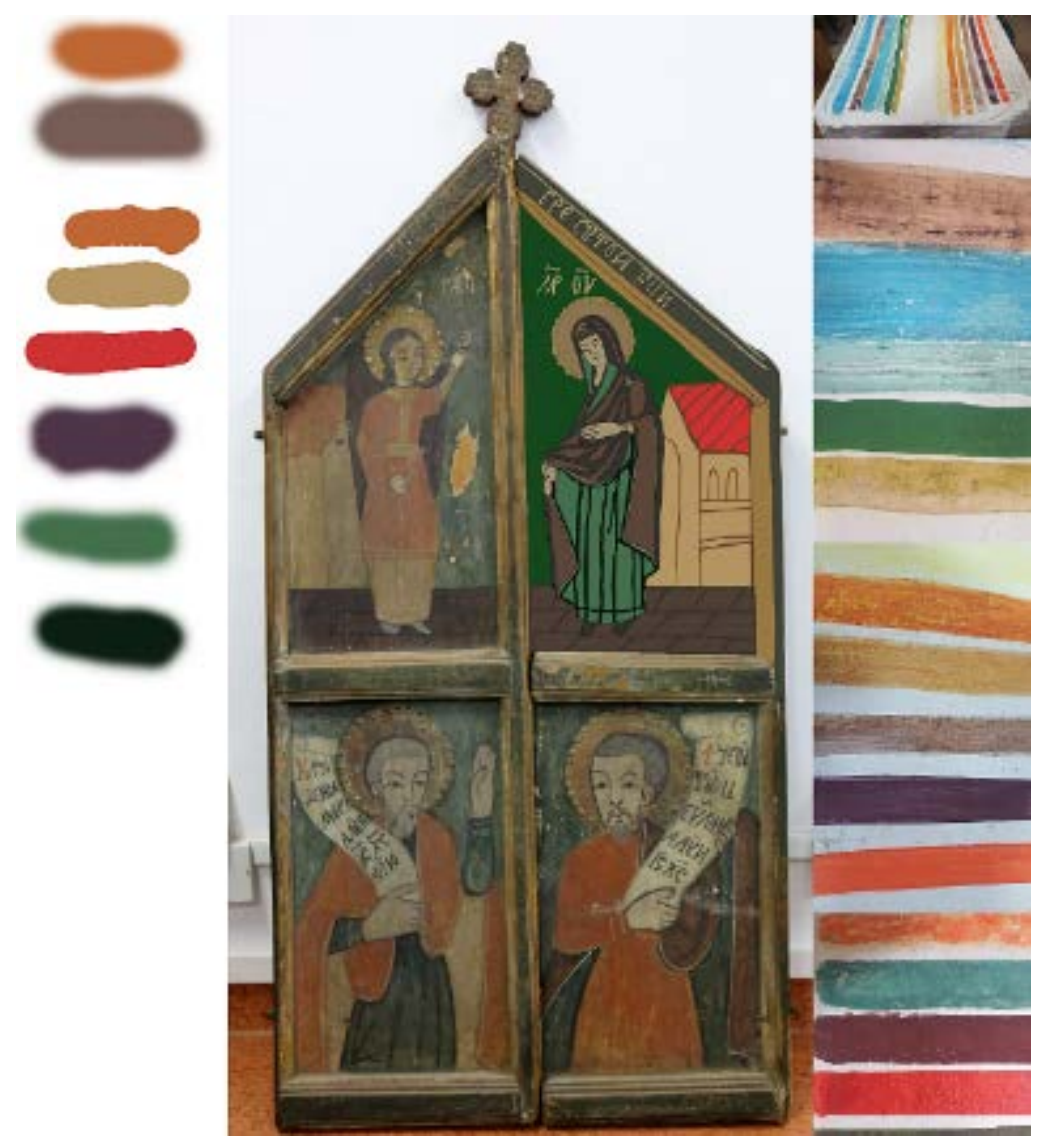

Figure 23. The digital repainting.

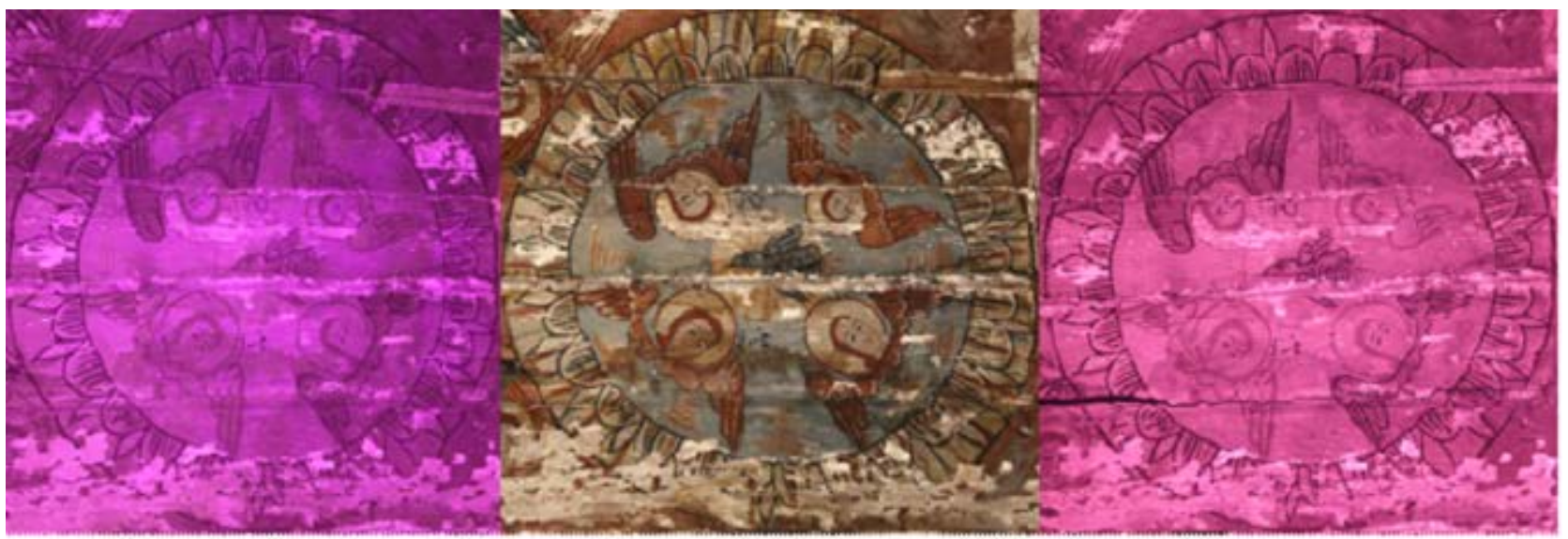

Figure 24. Detailed photography documentation within the visible spectrum, IR and UV.

The interior has been photographed in $360^{\circ}$ using an automatic photography system (Giga Pan-Figure 26), the shooting systems enables high resolution photography by combining multiple images of $50 \mathrm{Mpx}$ each with an overlap of $10 \%-15 \%$.

A set of HDR image (Figure 27) was obtained using the Z + F 5010X terrestrial laser scanner. This set enables the compositing and tone-mapping of images to extend the dynamic range capability. 


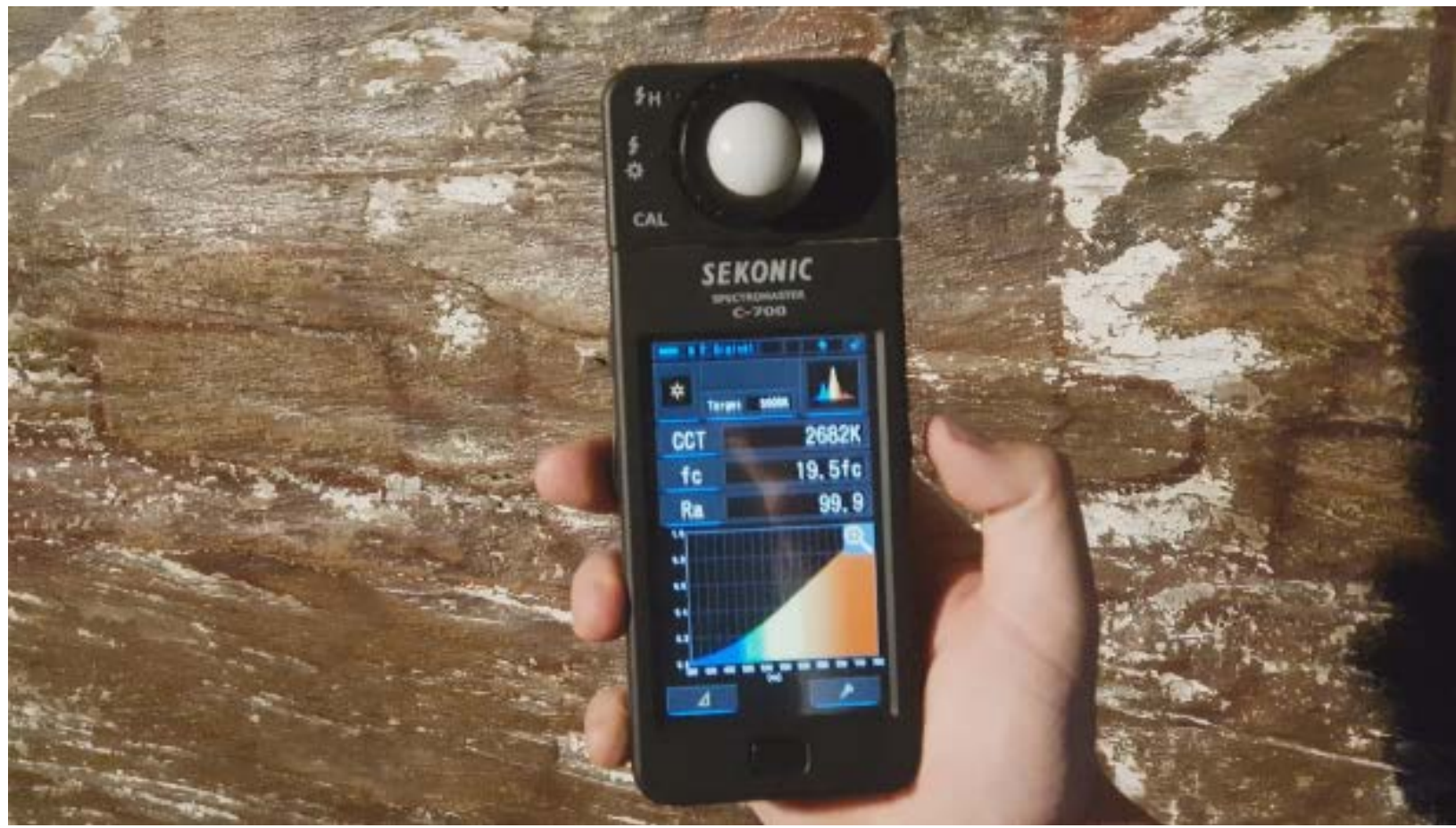

Figure 25. Parameter measurement during the photographic documentation inside the Wooden Church.

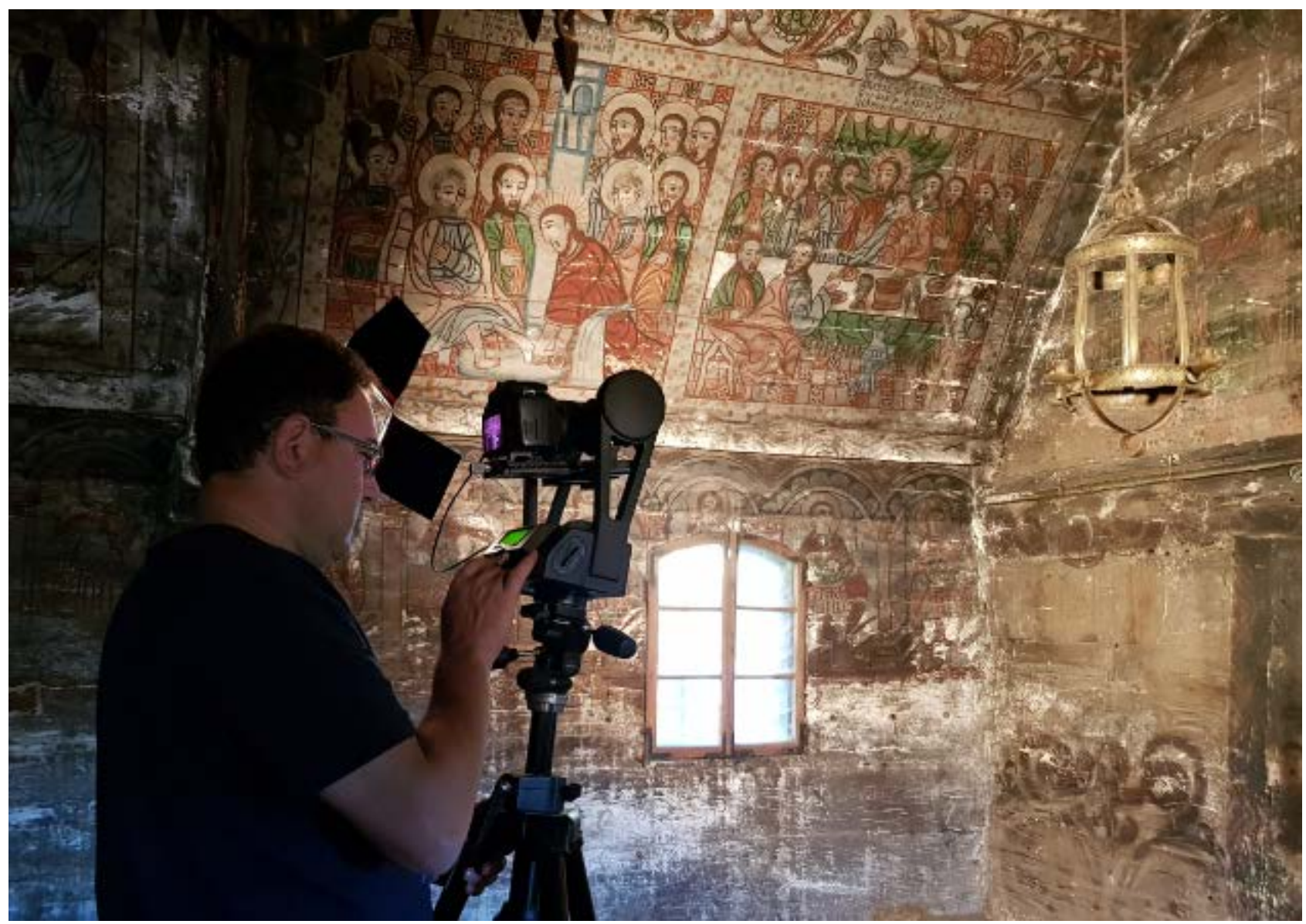

Figure $26.360^{\circ}$ photography of the church's interior. 
To record the exterior conservation status of the wooden church, a UAV was used to inspect the tower and roof structure. Based on the architecture of the wooden churches the exterior of the church tower is hard to inspect with traditional equipment. The church exterior has been recorded with a $4 \mathrm{k}$ camera (Figure 28) to enable the generation of the 3D model.

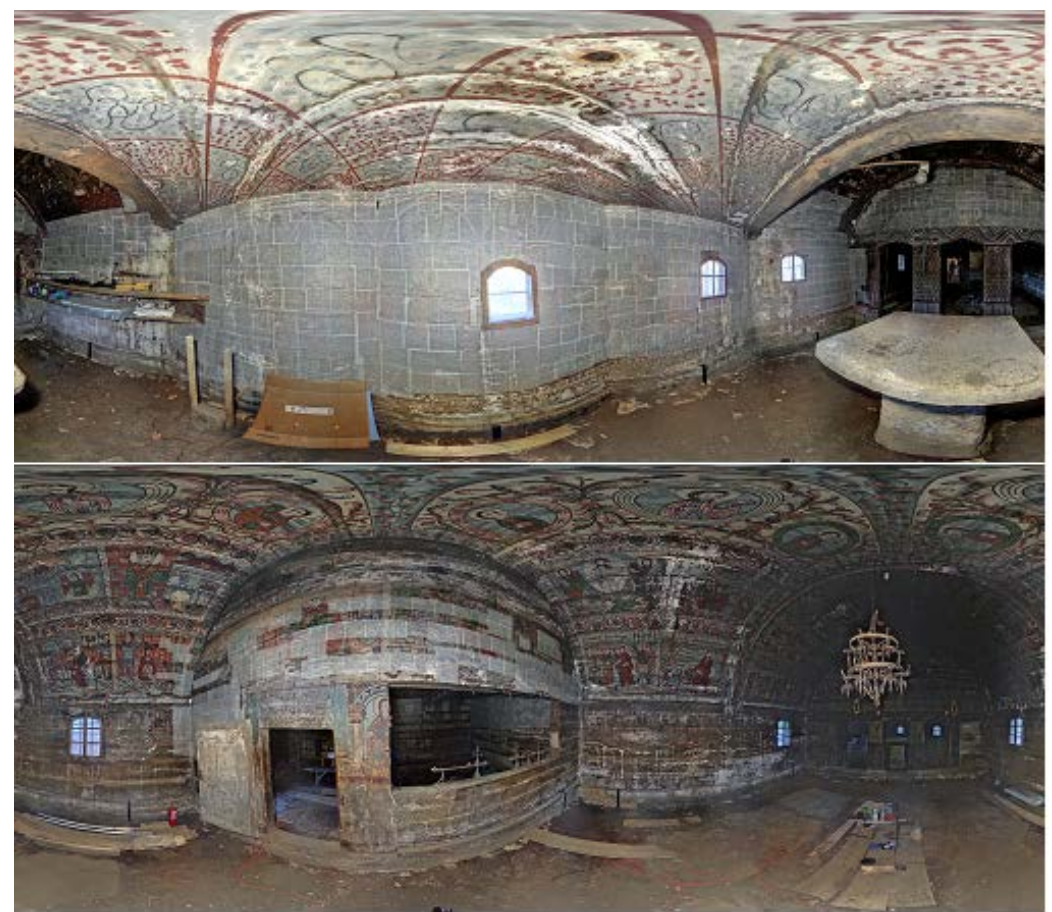

Figure 27. HDR images with the interior of the wooden church.

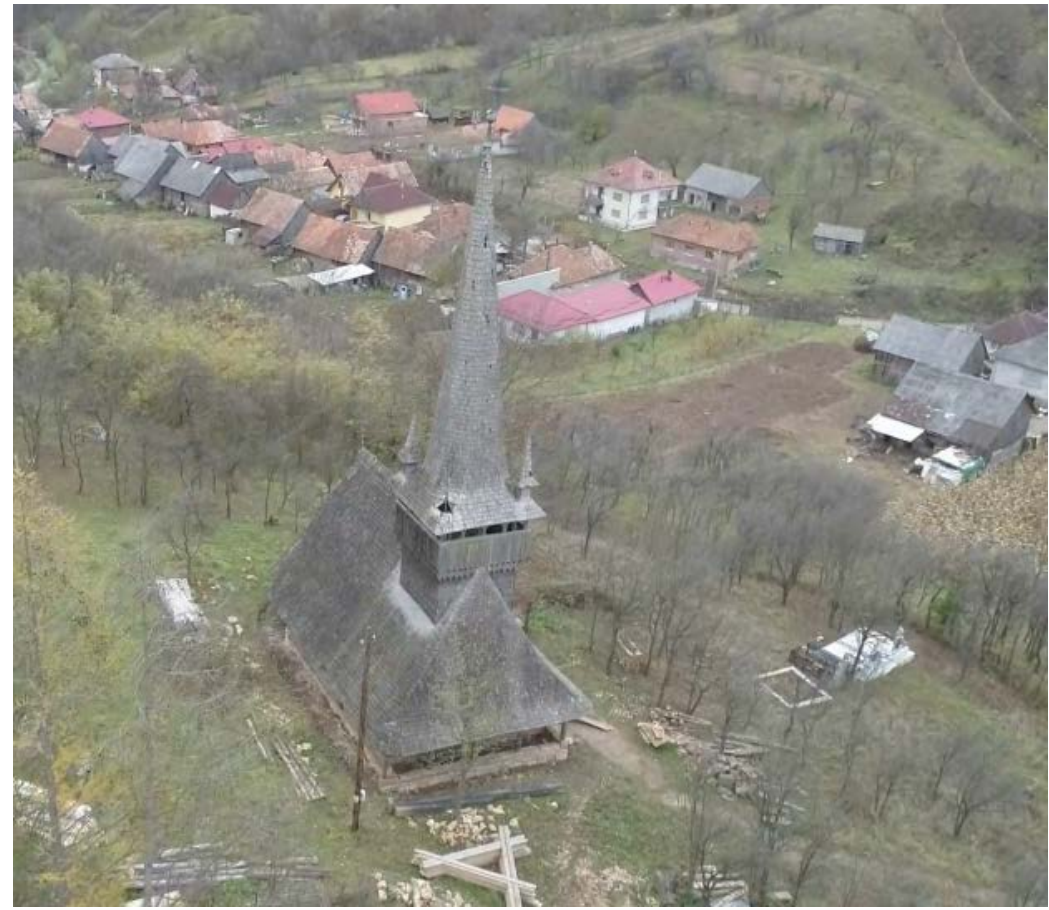

Figure 28. Using UAV in the digital documentation of the conservation status. 

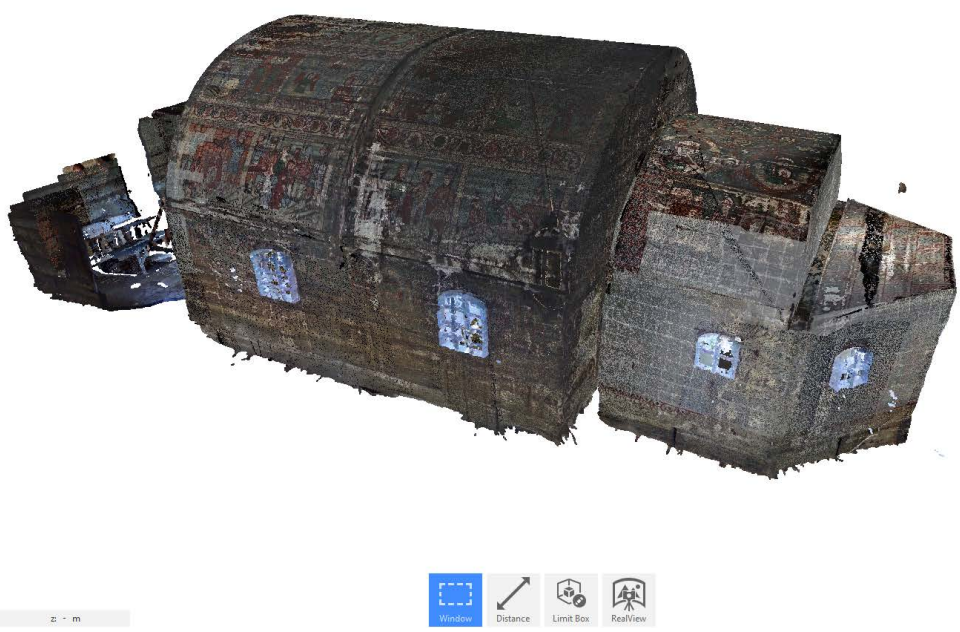

Figure 29. Using UAV in the digital documentation of the conservation status.

The interior has been $3 \mathrm{D}$ scanned using the $\mathrm{Z}+\mathrm{F}$ Imager $5010 \times$ terrestrial scanner, the model obtained has a resolution of $1 \mathrm{~mm}$, the texture has also been acquired and mapped to the 3D scanned model (Figure 29).

At the following link, all in-situ investigations for the Agârbiciu Wood church can be observed at the following link (https://youtu.be/RDzLErFioX0).

\section{Conclusions}

- Nave: gypsum ground, white Calcium, Iron black, Iron red, Lead red, yellow Arsenic (Orpiment), Prussian blue, malachite (green), binder-egg yolk, linseed oil.

- Narthex: gypsum ground, white Calcium, Carbon black, Iron red, Lead red, Mercury red, yellow Arsenic (Orpiment), Prussian blue, malachite (green), binder-linseed oil tempera, egg yolk.

Using multiple digitization techniques, the most important elements of the Agarbiciu wood church was acquired and preserved digitally. The availability of these data to the general public is problematic for now because of the large file size, which will be solved by using cloud solutions and improved bandwidth internet connections. At the following address:

(https://recap360.autodesk.com/project/49d75f68e850401c91c965e942de3ea6) a possible distribution of $3 \mathrm{D}$ scenes can be viewed. The digitization and digital preservation of the wooden churches is particularly important given that their current deteriorating status and the fact that in most cases these belong to small communities without sufficient financial resources to restore and preserve them.

\section{Disclosure}

Măruțoiu Constantin and Bratu Ioan are co-first authors. 


\section{Acknowledgements}

The paper was realised within the research project: „Elaborating Complex Methodologies Regarding the Attribution and Authentication of Certain Paintings from the Medieval and Early Modern Periods Belonging to the National Cultural Heritage", project number 53-PCCDI/2018, code: PN-III-P1-1.2-PCCDI-20170812 .

\section{Conflicts of Interest}

The authors declare no conflicts of interest regarding the publication of this paper.

\section{References}

[1] Cîmpian, F.E. (2002) Bisericile de lemn din zonele Călatei, Gilăului, Hășdatelor și Clujului. Aspecte istorico-etnografice și arhitectură tradițională. Risoprint, Cluj Napoca.

[2] Cîmpian, F.E. (2002) Pictura şi elementele decorative în bisericile de lemn din zonele Călatei, Gilăului, Hășdatelor și Clujului. Risoprint, Cluj Napoca.

[3] Cristache-Panait, I. (1980) Valențele istorice și artistice ale bisericilor de lemn din județul Cluj, propuse pe lista monumentelor. Revista Muzeelor și Monumentelor-Monumente Istorice și de Artă, 1, 32-41.

[4] Cristache-Panait, I. (1980) Decoraţia sculptată a monumentelor istorice din lemn din județul Cluj. Revista Muzeelor și Monumentelor-Monumente Istorice și de Artă, 1, 42-47.

[5] Cristache-Panait, I. (1981) Considerații privind tipologia monumentelor istorice de lemn din județul Cluj. Revista Muzeelor și Monumentelor-Monumente Istorice și de Artă, 1, 57-61.

[6] Pascu, Ș., Vătășianu, V. and Porumb, M. (1982) Monumente istorice și de artă religioasă din arhiepiscopia Vadului, Feleacului și Clujului. Arhiepiscopia Ortodoxă Română a Vadului, Feleacului și Clujului, Cluj Napoca.

[7] Neamtu, C., Marutoiu, V.C., Bratu, I., Marutoiu, O.F., Marutoiu, C., Chirila, I., Dragomir, M. and Popescu, D. (2018) Multidisciplinary Investigation of the Imperial Gates, of the 17th Century Wooden Church in Salisca, Cluj County, Romania. Sustainability, 10, 1503. https://doi.org/10.3390/su10051503

[8] Nemes, O.F., Bratu, I., Marutoiu, C., Kacso, I., Miclaus, M., Mihali, D. and Nica Badea, D. (2018) Spectroscopy Investigation of Triptych Icon from the Borsa Church, Maramures County. Revista de Chimie, 69, 76-79. https://doi.org/10.37358/RC.18.1.6047

[9] Marutoiu, O.F., Bratu, I., Marutoiu, C., Postolache, D.L., Dragomir, M., Tanaselia, C. and Garabagiu, S. (2018) Scientific Investigations of the Imperial Gates from the Petrindu Wooden Church, Salaj County, Romania. X-Ray Spectrometry, 47, 176-185. https://doi.org/10.1002/xrs.2827

[10] Marutoiu, C., Bratu, I., Nemes, O.F., Dit, I.-I., Comes, R., Tanaselia, C., Falamas, A., Miclaus, M., Marutoiu, V.C. and Moraru, R. (2017) Instrumental Analysis of Materials and Topology of the Imperial Gates Belonging to the Apahida Wooden Church, Cluj County. Vibrational Spectroscopy, 89, 131-136. https://doi.org/10.1016/j.vibspec.2017.02.003

[11] Bratu, I., Monk Siluan, Marutoiu, C., Kacso, I., Garabagiu, S., Marutoiu, V.C., 
Tanaselia, C., Popescu, D., Postolache, D.L. and Pop, D. (2017) Science Applied for the Investigation of Imperial Gate from Eighteenth Century Wooden Church of Nicula Monastery. Journal of Spectroscopy, 2017, Article ID: 6167856. https://doi.org/10.1155/2017/6167856

[12] Marutoiu, C., Nica, L., Bratu, I., Marutoiu, O.F., Moldovan, Z., Neamtu, C., Gardan, G., Rauca, A. and Sandu, I.C.A. (2016) The Scientific Investigation of the Imperial Gates Belonging to Sanmihaiul Almasului Wooden Church (1816). Revista de Chimie, 67, 1739-1744.

[13] Lee, J., Bonaduce, I., Modugno, F., La Nasa, J., Ormsby, B. and van den Berg, K.J. (2018) Scientific Investigation into the Water Sensitivity of Twentieth Century Oil Paints. Microchemical Journal, 138, 282-295. https://doi.org/10.1016/j.microc.2018.01.017

[14] van der Werf, I.D., Gnisci, R., Marano, D., De Benedetto, G.E., Laviano, R., Pellerano, D., Vona, F., Pellegrino, F., Andriani, E., Catalano, I.M., Pellerano, A.F. and Sabbatini, L. (2008) San Francesco d'Assisi (Apulia, South Italy): Study of a Manipulated 13th Century Panel Painting by Complementary Diagnostic Techniques. Journal of Cultural Heritage, 9, 162-171. https://doi.org/10.1016/j.culher.2007.10.003

[15] Llorent-Martínez, E.J., Domínguez-Vidal, A., Rubio-Domene, R., Pascual-Reguera, M.I., Ruiz-Medina, A. and Ayora-Cañada, M.J. (2014) Identification of Lipidic Binding Media in Plasterwork Decorations from the Alhambra Using GC-MS and Chemometrics: Influence of Pigments and Aging. Microchemical Journal, 115, 11-18. https://doi.org/10.1016/j.microc.2014.02.001

[16] Manzanoa, E., Rodriguez-Simónc, L.R., Navasa, N., Checa-Morenob, R., RomeroGámeza, M. and Capitan-Vallveya, L.F. (2011) Study of the GC-MS Determination of the Palmitic-Stearic Acid Ratio for the Characterisation of Drying Oil in Painting: La Encarnación by Alonso Cano as a Case Study. Talanta, 84, 1148-1154. https://doi.org/10.1016/j.talanta.2011.03.012 